9-30-2017

\title{
CEO's Inside Debt and Dynamics of Capital Structure
}

Eric Brisker

Wei Wang

Cleveland State University, w.wang24@csuohio.edu

Follow this and additional works at: https://engagedscholarship.csuohio.edu/bus_facpub

Part of the Corporate Finance Commons, and the Finance and Financial Management Commons How does access to this work benefit you? Let us know!

\section{Publisher's Statement}

"This is the peer reviewed version of the following article: Brisker, E. \& Wang, W. (2017). CEO's inside debt and dynamics of capital structure. Financial Management, 46 (3), 10.1111/

fima.12169, which has been published in final form at https://doi.org/10.1111/fima.12169. This article may be used for non-commercial purposes in accordance with Wiley Terms and Conditions for Use of Self-Archived Versions.

\section{Recommended Citation}

Brisker, Eric and Wang, Wei, "CEO's Inside Debt and Dynamics of Capital Structure" (2017). Business Faculty Publications. 285.

https://engagedscholarship.csuohio.edu/bus_facpub/285

This Article is brought to you for free and open access by the Monte Ahuja College of Business at EngagedScholarship@CSU. It has been accepted for inclusion in Business Faculty Publications by an authorized administrator of EngagedScholarship@CSU. For more information, please contact library.es@csuohio.edu. 


\title{
CEO's Inside Debt and Dynamics of Capital Structure
}

\author{
Eric R. Brisker and Wei Wang
}

\begin{abstract}
Debt-type compensation (inside debt) exacerbates the divergence in risk preferences between the chief executive officer (CEO) and shareholders and, in turn, affects capital structure decisions. An excessively risk-averse CEO tends to use less debt than the shareholders desire, reduce debt quickly when the firm is overlevered, but is reluctant to increase debt when the firm is underlevered. We find that higher CEO's inside debt ratio (i.e., inside debt as a percentage of total incentive compensation) is associated with lower firm leverage and faster (slower) leverage adjustments toward the shareholders' desired level for overlevered (underlevered) firms. The CEO's inside debt ratio most conducive to capital structure rebalancing is around $10 \%$ of the firm's market debt ratio.
\end{abstract}

Two well-known types of agency conflicts exist within corporations: that between managers and shareholders (separation of ownership and control) and that between shareholders and debtholders (asset substitution or risk shifting). One remedy proposed by Jensen and Meckling (1976) for these agency problems lies in the managerial compensation structure. On the one hand, firms could use equity-type compensation such as stock and stock options to align managers' interest with shareholders. On the other hand, debt-type compensation (sometimes called inside debt), including defined benefit pensions and deferred compensation, could incentivize managers to take debtholders' interests into account. ${ }^{1}$ They postulate that a manager whose compensation consists of both equity and debt, similar to the firm's debt and equity mix, would consider the interests of both shareholders and debtholders appropriately.

In this article, we empirically investigate the impact of inside debt on the capital structure dynamics of the firm. We consider how inside debt influences excessively risk-averse chief executive officers (CEOs) in setting firm leverage ratios and the speed of adjustment (SOA) of capital structure toward shareholders' desired level. Edmans and Liu (2011) provide an analytical model for deriving optimal compensation contracts, which include both inside equity and debt, for managers facing effort and investment (i.e., risk preference) choices. They find that while equity induces managerial effort, debt is part of the solution to the risk-shifting problem. In particular, because the value of debt hinges not only on the probability of bankruptcy, but also on the liquidation value if the firm fails, debt-type compensation serves as an efficient tool to address the risk-shifting problem and finds its place in the optimal compensation structure. They further determine that, in most cases, an equity bias (equity stake exceeding debt stake) in

We thank an anonymous reviewer and Raghavendra Rau (Editor) for their constructive comments.

\footnotetext{
${ }^{1}$ The term "inside debt" as used in the analytical models of Jensen and Meckling (1976) and Edmans and Liu (2011) refers to granting the executive a straight fraction of the firm's debt. Sundaram and Yermack (2007) confirm that certain forms of compensation widely observed in practice (e.g., pensions and other deferred compensation contracts) have debt-type payoffs and could potentially be viewed as inside debt. In this article, we use "debt-type compensation" and "inside debt" interchangeably. Likewise, in some places we use "inside equity" to refer to equity-type compensation.
} 
managerial compensation is optimal as the effort effect of equity-type compensation outweighs its "occasional risk-shifting" effect.

The effect of inside debt on managerial risk preference is in need of more in-depth exploration, especially when considering yet another type of agency problem: the divergence in risk preference between managers and shareholders. In the Edmans and Liu (2011) model, managers are assumed to be similar to well-diversified shareholders in that they are risk neutral. However, a substantial literature has argued that managers behave in a more risk-averse fashion than shareholders would prefer (Jensen and Meckling, 1976; Amihud and Lev, 1981; Smith and Stulz, 1985; Hirshleifer and Thakor, 1992; Klein and Coffee, 1996; Holmström, 1999; Gormley and Masta, 2016). Thus, managers are more aligned with debtholders than shareholders to begin with in terms of risk preference. Theoretically, offering managers equity-type compensation would encourage risk taking and mitigate managerial conservatism, but offering them debt-type compensation would have the unintended effect of exacerbating this agency problem. To the extent managers face the same asymmetric payoff structure for their inside debt holdings as outside debtholders (i.e., they receive fixed payoffs if the firm is successful, but bear the loss proportionally if the firm fails,) managers tend to act like debtholders (Bebchuk and Jackson, 2005). As a result, managers compensated with high stakes of inside debt could have the tendency to adopt excessively conservative business policies that would compromise shareholders' wealth.

Among the financial policies that are subject to managers' excessive conservatism, capital structure is of particular interest as inside debt is hypothesized to help balance the interests of outside shareholders and debtholders. Cassell et al. (2012) investigation provides some preliminary evidence in this regard, but it is not the focus of their paper nor is it adequate to fully reveal the relationship between managerial inside debt and firm leverage. In this article, we attempt to conduct a focused and full-fledged investigation of this issue.

The use of debt incurs the risk of bankruptcy that is often described as increasing convexly with the debt ratio. Excessively risk-averse managers would avoid lifting the debt ratio to the level that shareholders desire. Consistent with this conjecture, Liao, Mukherjee, and Wang (2015) find that firms, on average, are underlevered, falling short of using debt at the shareholders' desired level. Inside debt would aggravate managerial conservatism, so we hypothesize that managerial inside debt holdings negatively influence the firm's financial leverage. Moreover, the more risk-averse the manager is, the less likely he would adjust leverage upwardly if the firm is underlevered, but more likely he would adjust leverage downwardly if the firm is overlevered. Thus, our second hypothesis is that managerial inside debt holdings negatively affect the capital structure SOA of underlevered firms, but positively affect that of overlevered firms.

We use the CEO's Inside Debt Ratio as our measure of managerial inside debt holdings, defined as accumulated holdings of pensions and deferred compensation divided by total incentive compensation, where total incentive compensation includes pensions, deferred compensation, and the value of both stock and options. Using a sample of US firms from 2007 to 2013, we find that a CEO's inside debt ratio is quite persistent and it moves in tandem with the firm's debt ratio over calendar time. Over the length of the CEO's tenure, however, the two variables exhibit a mirror-image relationship. These patterns indicate the presence of common firm and time factors that shape both the CEO's inside debt and firm leverage, yet CEO's inside debt may have a negative within-firm effect on firm leverage. The estimation of an augmented capital structure dynamics model using the Elsas and Florysiak (2015) doubly censored fractional dependent variable estimator (DPF estimator) and the Blundell and Bond (1998) system generalized method of moments (GMM) estimator confirms our conjecture. We find that the CEO's inside debt ratio is negatively associated with firm leverage, and a one-standard deviation increase in CEO's inside debt leads to a nontrivial decrease of 1.7 percentage points in the firm's debt ratio. 
Based on the above estimates, we calculate shareholders' desired leverage, assuming that institutional shareholders own all of the outstanding shares and the CEO does not hold any inside debt. These hypothetical values of institutional ownership and CEO's inside debt are most likely to produce the capital structure that is desired by shareholders as they represent a situation where shareholders have a strong voice and managers' excessive conservatism is contained by equity compensation. Relative to our estimates of shareholders' desired leverage, more than $80 \%$ of our sample firms are underlevered. Further, we find that CEO's inside debt holding encourages an overlevered firm to adjust its leverage toward the shareholders' desired level, but impedes an underlevered firm from doing the same, consistent with our second hypothesis.

We address the potential endogeneity of CEO's inside debt by: 1) controlling for fixed firm and time effects, as well as a large array of firm and CEO characteristics, to alleviate omitted variable bias, and 2) using growth in the older population (persons 65 years or older) in the state where the firm is headquartered and the median industry inside debt ratio as instruments. Our rationale for using state-level growth in the older population is that CEOs located in popular migration destination states for the older population (i.e., Florida, California, etc.) might stay in their positions longer and have less need for pensions and deferred compensation. The results do not change after the instruments are employed. In addition, our results are qualitatively similar if firm leverage is measured based on market equity or book equity. We further estimate the capital structure SOA in subsamples for firms with different levels of CEO's inside debt ratios and find that SOA peaks when the CEO's inside debt ratio is around one-tenth of the firm's market debt ratio.

All of our findings indicate that offering debt-type compensation exacerbates managers' excessive conservatism when making capital structure decisions, which is detrimental to shareholder value. In the presence of the manager-shareholders conflict of interest in risk preference, optimal managerial compensation contracts would use less debt than postulated by Jensen and Meckling (1976), and a deep equity bias is probably necessary.

Our work differs from Cassell et al.'s (2012) investigation of capital structure in several ways. First, our measure of CEO's inside debt holding does not involve the firm's leverage ratio and avoids a mechanical negative relation between the measure of inside debt and the firm's debt ratio. Second, our dynamic panel model, using fixed firm effects, accounts for the strong persistence of capital structure (Lemmon, Roberts, and Zender, 2008). Failure to control for lagged leverage and unobservable firm heterogeneity would likely lead to an omitted variable bias. Additionally, when compared to Cassell et al.'s (2012) usage of three years of data, our longer sample period allows us to explore the dynamics of capital structure in a richer fashion.

\section{Related Literature}

Jensen and Meckling (1976), in explaining the agency cost of debt, conjecture that managers compensated with securities having payoffs similar to equity are incentivized to increase firm risk beyond levels debtholders prefer, and take actions that expropriate wealth from debtholders to shareholders through asset substitution. They suggest that compensating managers with securities having payoffs similar to debt is one way to reduce this agency cost of debt. In fact, they postulate that the agency cost of debt could be eliminated if the managers' compensation structure is set in a ratio equal to the firm's leverage ratio, as managers would be incentivized to consider the interests of both security holders appropriately.

Edmans and Liu (2011) argue that since creditors are concerned with the probability of bankruptcy, as well as the liquidation value when bankruptcy occurs, optimal compensation 
contracts should be sensitive to both. Debt-type compensation offers managers a payoff proportional to the liquidation value when bankruptcy occurs, which incentivizes them to avoid risk shifting and to exert more effort in protecting, or maximizing, liquidation values when bankruptcy becomes likely. They derive an optimal compensation contract that uses equity compensation as a solution to the manager-shareholder agency problem, as it induces managerial effort, and debt compensation as a solution to the shareholder-debtholder agency problem, as it discourages managers from risk-shifting behavior. They find that in most cases, an equity bias is optimal since equity is more effective than debt in incentivizing effort, even though it also causes risk shifting.

Risk-related agency conflicts also exist between managers and shareholders when undiversified managers have an incentive to take on less risk than is desired by diversified shareholders (Jensen and Meckling, 1976). This is because a manager's reputation and human capital greatly hinge on the success of the firm he runs. In addition, ownership of the firm's shares exposes the manager to substantial firm-specific risk. To offset the risk-aversion increasing effect of stock ownership, option-based compensation that provides a convex payoff structure is often used to encourage risk taking (Coles, Daniel, and Naveen, 2006). Managers sometimes even engage in value-destroying actions that lower firm risk in order to reduce the incidence of negative firm outcomes that are personally costly to the manager.

Previous literature regarding excessive conservatism of managers indicates it impacts firm's investment policy (Hirshleifer and Thakor, 1992), mergers and acquisitions (Amihud and Lev, 1981; Gormley and Masta, 2016), hedging behavior (Smith and Stulz, 1985), and capital structure decisions (Hirshleifer and Thakor, 1992). For instance, Gormley and Masta (2016) find that managers insulated by the adoption of a state-level antitakeover law engage in value-destroying, diversifying acquisitions that reduce their firms' stock volatility and risk of distress.

Empirical studies of managerial inside debt in recent years have been spurred by the pervasive use of debt-type compensation in large US corporations (Bebchuk and Jackson, 2005) and, particularly, the Securities Exchange Commission (SEC) disclosure rule in 2006 that mandates detailed disclosure of executive compensation structure to include pension and deferred compensation holdings. Sundaram and Yermack (2007) find a positive association between CEO's inside debt holding and the distance to default indicating that inside debt moderates the CEO's risk-shifting tendency. Other research finds that inside debt holding decreases (increases) the firm's cost of debt (equity) and decreases the firm's market risk levels (Wei and Yermack, 2011), lowers borrowing costs and reduces the use of debt covenants (Anantharaman, Fang, and Gong, 2014), reduces accounting conservatism (Wang, Xie, and Xin, 2014), and the riskiness of the firm's investment and financing policies (Cassell et al., 2012). In addition, inside debt holdings are positively associated with firm cash holdings (Liu, Mauer, and Zhang, 2014) and abnormal bond returns at merger and acquisition (M\&A) announcements (Phan, 2014), and negatively associated with cash holding value (Liu et al., 2014) and abnormal stock returns at M\&A announcements (Phan, 2014).

When capital structure policy is considered, the literature provides mixed results. Sundaram and Yermack (2007) confirm a positive relationship between the dollar amount of CEO's inside debt and firm leverage, while Cassell et al. (2012) demonstrate a negative association between a CEO's inside debt-to-equity ratio and firm leverage. However, due to data availability constraints, these initial investigations were largely cross-sectional and unable to consider the dynamics of capital structure that has been the core of recent capital structure studies (Flannery and Rangan, 2006; Lemmon et al., 2008; Faulkender et al., 2012; Morellec, Nikolov, and Schurhoff, 2012; Elsas and Florysiak, 2015). The cross-sectional relationship between firm capital structure and CEO's compensation structure, both highly persistent, may develop simply because they are determined by a set of common factors. Exploring the dynamics of capital structure could mitigate this 
concern. In addition, Cassell et al.'s (2012) findings are based on the relative CEO's debt-toequity ratio, which is the CEO's debt-to-equity ratio divided by the firm's debt-to-equity ratio that could give rise to a mechanical negative relation between inside debt and a firm's debt ratio. ${ }^{2}$ Our measure separates CEO's inside debt from the firm's financial leverage and, as such, is not subject to the mechanical relation problem.

Our study is also closely related to the empirical literature on capital structure dynamics. The tradeoff theory dictates the existence of an optimal capital structure level (or range). In the event of a shock to capital structure, firms should rebalance their capital structure to eliminate the deviation. In an effort to reveal whether and how fast firms adjust toward an optimal capital structure, many authors, including Fama and French (2002), Flannery and Rangan (2006), Lemmon et al. (2008), Huang and Ritter (2009), and Elsas and Florysiak (2015), estimate a dynamic panel partial adjustment model with various estimation approaches. ${ }^{3}$ Monte Carlo simulations conducted by Flannery and Hankins (2013) and Dang, Kim, and Shin (2015) find that the Elsas-Florysiak (2015) DPF estimator and the Blundell-Bond (1998) system GMM estimator produce consistent estimates. Faulkender et al. (2012), Warr et al. (2012), and Liao et al. (2015) use this dynamic panel model to estimate target leverage. Then, in the second step, they estimate the heterogeneous SOAs toward this target that hinge on factors including cash flows and corporate governance. We will employ a similar procedure.

\section{Data and Methodology}

\section{A. Variables}

\section{Main Variables}

The key variables in this study are the firm's capital structure and the CEO's inside debt holdings. A firm's capital structure is measured by the debt-to-capital ratio, where debt is the sum of long-term debt and debt in current liabilities and capital is the sum of total debt and the market value of common equity. The market value of equity is calculated as the product of the number of shares outstanding and the stock price at the end of a fiscal year. For robustness, we also employ the book leverage ratio, which is total debt divided by the sum of debt and book value of common equity, in all of our tests. We also use the alternative measure of debt as total liabilities plus preferred stock minus deferred taxes with the results being qualitatively similar.

The literature provides a few measures of inside debt with most based on the comparison between the CEO's inside debt holdings and the firm's debt holdings (Wei and Yermack, 2011; Cassell et al., 2012) in an effort to capture the incentive effect of inside debt. Since our purpose is to examine the link between inside debt and firm leverage, we remove firm leverage from the measure of inside debt in most of our investigation. To create an analog to our firm leverage measure, we use the CEO's inside-debt-to-incentive-compensation ratio, which is the ratio of

\footnotetext{
${ }^{2}$ Cassell et al. (2012) acknowledge this potential drawback of their measure and warn that their "analyses investigating the association between the relative CEO's debt-to-equity ratio and financial leverage should be interpreted with caution" (p. 592).

${ }^{3}$ Hovakimian and Li (2012) critique the partial adjustment model as "ill-suited" citing the lack of a well-defined target. DeAngelo and Roll (2015), however, fit the data well with the partial adjustment model and different target formations supporting the validity of the model.
} 
debt-type compensation to total incentive compensation. ${ }^{4}$ Debt-type compensation is found as the sum of the present value of accumulated pension benefits and deferred compensation. Incentive compensation also includes equity-type compensation (i.e., stock holdings, restricted shares, and options). The value of stock is equal to the number of shares, including restricted shares, the CEO holds multiplied by the stock price at the firm's fiscal year-end. Following the literature, particularly Cassell et al. (2012), we estimate the value of each individual tranche of exercisable and unexercisable options the CEO holds using the Black-Scholes (1973) option model adjusted for dividends based on Merton (1973). We then find the sum of these option tranche values to form the total value of option holdings for the CEO. ${ }^{5}$ Nevertheless, we recognize that the comparison between CEO's inside debt holdings and the firm's debt holdings is of particular interest when considering what level of inside debt is optimal for capital structure decisions, so we create the CEO/Firm Relative Debt Ratio as the CEO's inside debt ratio divided by the firm's market debt ratio. This measure is essentially equivalent to the CEO to Firm Relative Debt/Equity Ratio in Cassell et al. (2012). We winsorize this measure at the 99th percentile to avoid extreme values caused by zero or a very low firm debt ratio in the denominator.

\section{Control Variables}

There are two sets of control variables for the determination of firm leverage levels and firm leverage adjustments, respectively. Some firm characteristics, including firm size (Total Assets), the Market-to-Book Ratio, Profitability, Asset Tangibility, Depreciation, and research and development $(R \& D)$ expenses, are known to impact the benefits and/or costs of debt (Flannery and Rangan, 2006). When $R \& D$ is missing, a value of zero is used and a separate dummy variable is set equal to one. We also include the median value of the debt-to-capital ratio of a two-digit standard industrial classification (SIC) industry to control for industry effects. Corporate governance is controlled for using the percentage of Independent Directors on the firm's board and Institutional Ownership as in Morellec et al. (2012) who find that good corporate governance encourages the use of debt. We control for CEO Age as in Sundaram and Yermack (2007) who determine that inside debt increases with the age of the CEO. Serfling (2014) also finds a negative relation between CEO Age and firm riskiness that could indicate older CEOs avoid using debt. CEO Tenure is another control as CEOs with longer tenures are more likely to be entrenched and more risk averse (Berger, Ofek, and Yermack, 1997; Coles et al., 2006). Finally, the CEO's Vega/Delta Ratio controls for the effects of equity-type compensation on CEO risk preference. The Vega and Delta measure the sensitivity of the value of the CEO's accumulated equity-type compensation to a $1 \%$ change in the volatility of stock prices and to a $1 \%$ change in the stock price, respectively. Similar to Cassell et al. (2012), we use the logarithm of the Vega/Delta ratio as a parsimonious measure. ${ }^{6}$

In the capital structure SOA model, we control for factors that the literature has identified as influencing a firm's leverage rebalancing decisions. Jalilvand and Harris (1984) confirm that capital structure adjustment costs, and, as such, SOA, are affected by firm size. Fama and French (2002) contend that dividend policy is a determinant of a firm's capital structure and examine SOAs for dividend payers and nondividend payers separately. Liao et al (2015) test the empirical implications of Morellec et al. (2012) and find that well-governed firms exhibit faster SOAs as their managers are more willing to move leverage upward toward the shareholders'

\footnotetext{
${ }^{4}$ For comparison with the literature, we also create an inside debt-to-equity ratio as the value of debt-type compensation divided by equity-type compensation. Its summary statistics, reported in Table I, are consistent with the literature.

${ }^{5}$ For more details, please see Cassell et al. (2012) in Appendix A.

${ }^{6}$ In alternative specifications, we use the Vega and Delta separately and all the main results remain unchanged.
} 
desired level. We use the fraction of Independent Directors and Institutional Ownership as measures of corporate governance. CEO Age tenure, and equity-type compensation influence CEO's incentives and could affect the capital structure adjustments as well. Detailed variable descriptions are provided in Appendix A.

\section{B. Data}

We extract information regarding CEOs' pension benefits and deferred compensation, as well as their stock and option holdings, for S\&P 1500 firms from the Standard \& Poor's ExecuComp database. The SEC expanded executive compensation disclosure requirements that mandate the provision of detailed information regarding executive pension benefits and deferred compensation began in 2006. As such, we begin our sample period in 2007. We then supplement the executive compensation data with annual financial data from Compustat and fiscal year-end stock price data from the Center for Research in Security Prices (CRSP). We require a firm to have all of the compensation, financial, and stock price data available for at least two consecutive years to be included in the sample. Our final sample consists of 10,015 observations for 1,874 firms from 2007 to 2013.

\section{Methodology}

The conventional partial adjustment model of capital structure dynamics is:

$$
\Delta L_{i t}=\lambda D_{i t}+\varepsilon_{i t}
$$

where $L_{i t}$ denotes the leverage ratio of firm $i$ at the end of period $t$ and $\Delta L_{i t}=L_{i t}-L_{i, t-1}$ is the adjustment in leverage during period $t$. Note that $D_{i t}=L_{i t}^{*}-L_{i, t-1}$ is the deviation from the target leverage ratio, $L_{i t}^{*}$, at the beginning of period $t . \varepsilon_{i t}$ is the error term. In this model, $\lambda$ captures the fraction of leverage deviation that is removed in period $t$ and this estimated coefficient is the SOA. When $\lambda=1$, the adjustment is complete. Depending upon the estimator used, the estimated average SOA ranges from 0.10 to 0.40 (Fama and French, 2002; Flannery and Rangan, 2006; Lemmon et al., 2008; Huang and Ritter, 2009; Faulkender et al., 2012; Elsas and Florysiak 2015).

Following the literature, the target leverage ratio, $L_{i t}^{*}$, is expressed as a linear combination of leverage-determining factors, $L_{i t}^{*}=\boldsymbol{\beta} \boldsymbol{X}_{i, t-1}$, where $\boldsymbol{X}_{i, t-1}$ represents those factors including a fixed firm effect (Lemmon et al., 2008), fixed time effects, a set of time-varying firm characteristics as mentioned earlier (Flannery and Rangan, 2006), the median industry leverage ratio, and corporate governance variables (Liao et al., 2015). We supplement the list of determinants with CEO-related variables, including age, tenure, the Vega/Delta ratio, and the inside debt ratio, to capture the effect of CEO compensation structure on the firm's financial leverage. Model (1) can then be rewritten as:

$$
L_{i t}=(1-\lambda) L_{i, t-1}+\lambda \boldsymbol{\beta} \boldsymbol{X}_{i, t-1}+\varepsilon_{i t}
$$

This specification allows us to examine the effect of CEO's inside debt on firm leverage. The large cross-section and short time series of financial data present great difficulties in estimating this dynamic panel model (for discussion, please see Iliev and Welch, 2010; Flannery and Hankins, 2013) and the dependent variable in the range of $[0,1]$ further complicates this situation. Out of all of the existing estimators, the simulation work of Dang et al. (2015) finds that an augmented 
doubly censored Tobit estimator proposed by Elsas and Florysiak (2015), dubbed DPF estimator, produces estimates with the greatest accuracy and efficiency. The DPF estimator, assuming a parametric specification for the fixed effects distribution, uses a latent variable approach to account for the fractional and endogenous lagged dependent variable as well as the unobserved firm heterogeneity simultaneously. ${ }^{7}$ Thus, we employ the DPF method as our baseline estimator for Model (2). In addition, because the Blundell and Bond (1998) system generalized method of moments (GMM) has become virtually the standard estimator in the recent capital structure literature (Lemmon et a1., 2008; Faulkender et al., 2012; Liao et al., 2015), we also use the system GMM to estimate Model (2) for robustness. ${ }^{8}$

To probe the effect of CEO's inside debt holdings on capital structure adjustments, we conduct both univariate and multivariate analyses. For the univariate analyses, we follow Faulkender et al. (2012) and Warr et al. (2012) to estimate Model (1) using ordinary least squares (OLS) in subsamples partitioned according to CEO's inside debt holdings, with the target leverage, $L_{i t}^{*}$, as the predicted value from Model (2). For the multivariate analyses, we modify Equation (1) as follows to allow for CEO's inside debt and other factors to affect SOA:

$$
\Delta L_{i t}=\left(\lambda_{0}+\lambda_{1} E_{i, t-1}+\lambda_{2} C_{i, t-1}\right) D_{i t}+\varepsilon_{i t},
$$

where $E_{i, t-1}$ denotes the CEO's inside debt ratio and $\boldsymbol{C}_{i, t-1}$ is the set of control variables discussed earlier. To the extent that macroeconomic conditions affect capital structure adjustments (Korajczyk and Levy, 2003; Cook and Tang, 2010), fixed time effects are controlled for with yearly dummies (but not reported in our tables). Note that $\lambda_{1}$ is the primary variable of interest, measuring the effect of CEO's inside debt holdings on capital structure SOA. $\lambda_{2}$ is the vector of coefficients on the interaction items between the control variables and firm leverage deviations. Since firm leverage deviation, $D_{i t}$, is generated from a first-step regression, we use bootstrapped standard errors (Pagan, 1984).

\section{Endogeneity}

The identification of the relation between CEO's inside debt and firm leverage entails appropriately addressing the endogeneity issue present in empirical corporate finance research (Roberts and Whited, 2013). In our case, endogeneity may arise as unobserved firm and/or CEO heterogeneity determines both CEO's inside debt holdings and firm leverage. For instance, the elasticity of demand for the firm's products to prices, which is often difficult to measure, is among the factors that determine the firm's business risk, which, in turn, influences the firm's capital structure policy, as well as executive compensation. As another example, an optimistic CEO might be more willing to use debt financing and defer his own compensation, but the CEO's optimism is not observable. Lemmon et al. (2008) find that unobservable firm heterogeneity creates the strong persistence of capital structure that accounts for $60 \%$ of the variation in debt ratios. In Figure 1(a), we illustrate that the CEO's inside debt ratio also exhibits strong persistence with firms that start with high (low) CEO's inside debt ratio ending up with a high (low) CEO's inside debt ratio. This implies the existence of time-invariant firm heterogeneity in the CEO's inside

\footnotetext{
${ }^{7}$ This approach is initiated by Loudermilk (2007) for balanced panel model estimation. Elsas and Florysiak (2015) extend it to the case of unbalanced panels and name it DPF.

${ }^{8}$ Flannery and Hankins (2013), based on Monte Carlo simulations, find that the Blundell-Bond (1998) system GMM estimator produces consistent estimates in capital structure dynamics models. Dang et al. (2015, p. 85), notwithstanding, find that the system GMM estimates to be "sensitive to the presence of unobservable heterogeneity and serially correlated errors where their instruments become invalid."
} 


\section{Figure 1. Firm Debt and CEO Debt Over Time}

(a) The average debt ratio of firms in the three terciles (high, intermediate, and low) over time during the firms' event period. Firms are classified into subsamples based on their initial debt ratio. (b) lhe average firm's debt ratio and the CEO's inside debt ratio in the full sample over the sample period. (c) The average of the same two variables over the CEO's tenure.
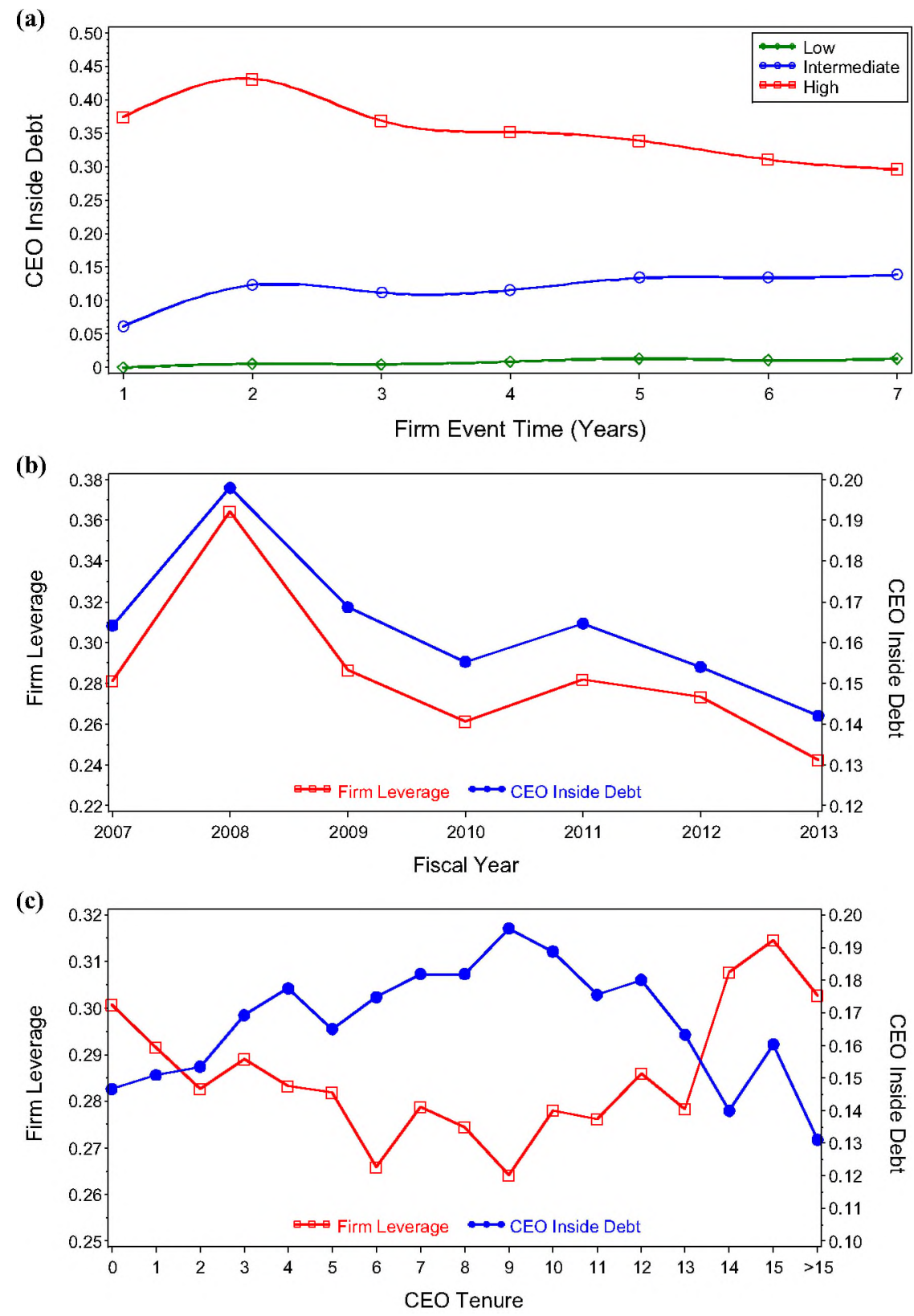
debt holdings. Thus, endogeneity due to omitted variables is indeed a valid concern. In addition, reverse causality can be a problem. For instance, a CEO hired by a highly levered firm may be concerned about the long-run survival of the firm, and may be more willing to accept equity-type compensation than debt-type compensation.

We take a two-pronged approach to address endogeneity concerns in our model. First, in addition to controlling for many observable firm characteristics (e.g., firm size, Market-to-Book Ratio corporate governance, etc.) and CEO characteristics (e.g., age, tenure, and Vega/Delta ratio), we use fixed firm effects to account for unobservable firm heterogeneity. ${ }^{9}$ This practice would ameliorate the concern of omitted variables.

In addition, we employ an instrumental variable approach to establish the causality from CEO's inside debt to firm leverage. We use as an instrument the growth of the older population (persons 65 years or old) between the 2000 and 2010 censuses in the state where the company is headquartered.$^{10}$ CEOs in popular migration destination states for the older population, like Florida and California, might stay in their positions longer and have less need for pensions and deferred compensation. The state-level growth of the older population is negatively associated with the CEO's inside debt holdings $(\rho=-0.15)$ and is unlikely to have a direct association with a firm's capital structure. Another instrument is the median CEO's inside debt holdings of the two-digit SIC industry in each year (Cassell et al., 2012) as CEOs of same-industry firms are likely to imitate their compensation structures. In a two-stage framework, we regress CEO's inside debt ratio on these instruments, as well as firm and CEO characteristics, in the first-stage OLS estimation and use the predicted value in the second-stage DPF estimation of Model (2).

\section{Results}

\section{A. Descriptive Statistics}

Table I presents the descriptive statistics of all the variables included in our tests. The firm market (book) debt ratio averages $0.285(0.398)$ with a median of $0.241(0.381)$. CEO's inside debt ratio averages 0.164 with a median of 0.064 and a standard deviation of 0.212 . These statistics are similar to Sundaram and Yermack (2007). While inside debt accounts for a very small percentage of total CEO incentive compensation in a majority of firms, there exists a great variation in inside debt holdings across firms. Consistent with this, CEO/Firm Relative Debt Ratio on average, is greater than one, but this is attributable to the severe skewness to the right even after winsorizing this variable to the 99 th percentile. The median of relative leverage is 0.295 , the maximum is 46.5 , and the standard deviation is 5.4. Decomposing inside debt into pension benefits and deferred compensation, we find the former accounts for $9.6 \%$ and the latter for $6.8 \%$ of $\mathrm{CEO}$ incentive compensation.

The CEO Vega/Delta Ratio averages 0.417 with a median of 0.329 , similar to what Cassell et al. (2012) report. The age of CEO ranges from 41 to 74 averaging 56. The average (median) CEO Tenure in our sample is 7.2 (5) years. Roughly $80 \%$ of directors are independent. Note

\footnotetext{
${ }^{9} \mathrm{CEO}$ fixed effects are not considered. The inclusion of these effects would substantially reduce the sample size and shorten the length of the time period for the sample firms as a large number of CEOs whose tenures do not exceed two years would be excluded.

${ }^{10}$ State-level population data are from the US Census Bureau. We considered both the logarithm of increase in the older population and the percentage growth rate of the older population, and chose the former as the absolute change better reflects the scale of migration of the older population across states. Furthermore, its correlation with CEO's inside debt ratio is greater in magnitude.
} 


\section{Table I. Descriptive Statistics}

This table presents the descriptive statistics of the variables used in the paper. Variables definitions are provided in Appendix A.

\begin{tabular}{lccccc}
\hline \hline Variable & Mean & Median & $S D$ & 1st Percentile & 99th Percentile \\
\hline Firm Market Debt Ratio & 0.285 & 0.241 & 0.218 & 0 & 0.902 \\
Firm Book Debt Ratio & 0.398 & 0.381 & 0.245 & 0 & 0.990 \\
CEO Inside Debt Ratio & 0.164 & 0.064 & 0.212 & 0 & 0.826 \\
CEO Debt/Equity Ratio & 0.363 & 0.069 & 0.748 & 0 & 4.755 \\
CEO/Firm Relative Debt Ratio & 1.503 & 0.295 & 5.426 & 0 & 46.48 \\
CEO Pension Benefits & 0.096 & 0 & 0.171 & 0 & 0.719 \\
CEO Deferred Compensation & 0.068 & 0.010 & 0.120 & 0 & 0.608 \\
CEO Vega/Delta Ratio & 0.417 & 0.329 & 0.395 & 0 & 1.718 \\
CEO Age & 55.8 & 56 & 6.8 & 41 & 31 \\
CEO lenure & 7.2 & 5 & 6.7 & 0 & 0.923 \\
Outside Directors & 0.795 & 0.8 & 0.096 & 0.538 & 0.999 \\
Institutional Ownership & 0.758 & 0.795 & 0.191 & 0.016 & 271,205 \\
Total Assets (\$million) & 13,982 & 3,160 & 36,833 & 98 & 4.835 \\
Market-to-Book Ratio & 1.216 & 0.991 & 0.951 & 0.127 & 0.384 \\
Profitability & 0.113 & 0.111 & 0.105 & -0.167 & 0.883 \\
Asset Tangibility & 0.252 & 0.164 & 0.244 & 0.001 & 0.143 \\
Depreciation & 0.038 & 0.033 & 0.033 & 0.000 & 0.215 \\
R\&D & 0.020 & 0 & 0.052 & 0 & 1 \\
R\&D Missing Dummy & 0.513 & 1 & 0.500 & 0 & 1 \\
Dividend Payer Dummy & 0.592 & 1 & 0.492 & 0 & \\
\hline \hline
\end{tabular}

that the first percentile for the fraction of Independent Directors is $54 \%$. Thus, essentially all of the firms in our sample have a majority of Independent Directors on their boards in compliance with the Sarbanes-Oxley Act (SOX) requirement. The lack of variation in the extent of board independence may obscure the differential monitoring effect of Independent Directors. On average, institutional shareholders own about $76 \%$ of the outstanding shares of our sample firms.

Our average sample firm owns assets just below $\$ 14$ billion USD, commands a Market-to-Book Ratio of 1.216, and an operating Profitability ratio of 11.3\%. Tangible assets, Depreciation, and $R \& D$ expenses account for $25.2 \%, 3.8 \%$, and $2.0 \%$ of Total Assets respectively. About $51 \%$ of the sample firms do not report $R \& D$ expenses, and $59 \%$ pay dividends. In general, our sample firms are similar to those in the literature.

\section{B. Firms That Do Not Use Debt-Type Compensation}

Many of our sample firms use little debt-type compensation as shown in the descriptive statistics. Further examination finds that 3,210 firm-year observations, representing nearly onethird of all of the observations, have zero CEO's inside debt. Zero inside debt most likely occurs when the initiation and management costs of pension and/or deferred compensation plans outweigh their benefits. ${ }^{11}$ Given that pension and deferred compensation plans may or may

\footnotetext{
${ }^{11}$ Anecdotal evidence indicates that small firms are less likely to offer pension plans than large firms due to a lack of resources. For instance, in 2011, in a US News \& World Report article, a retirement consultant is cited, "Having a pension plan is a fairly complicated thing to do and you need some resources to be able to deal with it .... A small company probably doesn't want to deal with all the hassle when they can sign up for a 401(k) plan fairly easily."
} 
not be offered for a variety of different reasons (Sundaram and Yermack, 2007), one possible explanation that firms avoid this type of compensation could be related to the unintended adverse incentive effect it offers against shareholders (i.e., the effect of aggravating managerial risk aversion). Overall, zero inside debt represents the censoring point of the variable. It is of interest to determine whether these firms are different from firms that use inside debt in their CEOs' compensation packages.

In Table II, we present the comparison between firms with zero CEO's inside debt and those with nonzero inside debt in terms of capital structure, inside debt, and CEO and firm characteristics. For each variable, the mean and median are reported for both subsamples and the differences in mean and median are shown in the last two columns on the right. Two sample $t$-tests and two sample Brown-Hood tests, respectively, are employed to determine the statistical significance of the differences in mean and median. Firms that use debt-type compensation borrow more, have higher CEO Vega/Delta Ratios are greater in size, more profitable, own more tangible assets, have lower depreciation of assets, invest less in $R \& D$, and are more likely to pay dividends. Essentially larger, more mature firms are more likely to use debt-type compensation. These firms have relatively older CEOs, but they are not much different from their zero inside debt counterparts in terms of CEO Tenure, board independence, or Institutional Ownership despite the statistical significance of some of the differences. In short, firms that use debt-type compensation differ from those that do not in firm characteristics, but not necessarily in CEO characteristics and corporate governance.

It is worth noting that even zero inside debt firms, which commonly offer equity-type compensation to their CEOs, could suffer from managerial conservatism for two reasons. First, it is difficult to kill two birds with one stone. While equity-type compensation often seeks to induce effort it unlikely cures managerial conservatism completely at the same time. Second, the riskshifting effect of equity compensation stems from the convexity of its payoff, which is probably not adequate to align managers' preference with shareholders who face similar convex payoffs as managers are underdiversified when compared to shareholders. Therefore, despite their equity compensation, managers could still use less financial leverage than shareholders desire and be reluctant to adjust leverage when it is below the shareholders' desired level.

\section{CEO's Inside Debt and Level of Firm Leverage: Univariate Analysis}

We examine the correlation between the firm's debt ratio and the CEO's inside debt ratio in Table III. A fairly large positive correlation ( $\rho$ at the level of 0.2 ) exists between the firm's debt ratio and the concurrent CEO's inside debt ratio, as well as the lagged CEO's inside debt ratio. The components of CEO's inside debt, pensions, and deferred compensation are also positively correlated with the firm's debt ratio. The change in firm's debt ratio and CEO's inside debt ratio has a positive coefficient of 0.33 . All of these positive associations could stem from common factors that determine both variables, such as firm characteristics and time effects. When we review the correlations of the change in the firm's debt ratio with both the levels of the firm's debt ratio and the CEO's inside debt ratio, we find interesting contrasts. The change in the firm's debt ratio is positively associated with the level of the concurrent firm's debt ratio and CEO's inside debt, slightly negatively associated with the level of the firm's debt ratio in the previous period $(\rho=-0.08)$, but much more strongly negatively correlated with the level of the CEO's inside debt ratio in the previous period $(\rho=-0.27)$. Its correlations with lagged CEO pensions and deferred compensation are also negative ( $\rho=-0.20$ and -0.19 , respectively). The patterns in the correlations seem to indicate that despite the possible presence of common drivers for both firm 


\section{Table II. Firms with and without CEO's Inside Debt}

This table presents the mean and median of variables used for firms whose CEOs hold inside debt and for those whose CEOs do not hold inside debt. Iwo-sample $t$-tests and the two-sample Brown-Hood tests, respectively, are conducted to report the statistical significance of differences in mean and median across the two subsamples.

\begin{tabular}{|c|c|c|c|c|c|c|}
\hline \multirow[b]{2}{*}{ Variable } & \multicolumn{2}{|c|}{$\begin{array}{l}\text { Zero Inside Debt } \\
\quad(n=3,212)\end{array}$} & \multicolumn{2}{|c|}{$\begin{array}{c}\text { Nonzero Inside Debt } \\
(n=6,803)\end{array}$} & \multicolumn{2}{|c|}{ Difference In } \\
\hline & Mean & Median & Mean & Median & Mean & Median \\
\hline $\begin{array}{l}\text { Firm Market } \\
\text { Debt Ratio }\end{array}$ & 0.254 & 0.195 & 0.300 & 0.254 & $0.046^{\text {*k* }}$ & $0.060^{\text {*k* }}$ \\
\hline $\begin{array}{l}\text { CEO Inside } \\
\text { Debt Ratio }\end{array}$ & 0.000 & 0.000 & 0.242 & 0.181 & $0.242^{* * *}$ & $0.181^{\text {*** }}$ \\
\hline $\begin{array}{l}\text { CEO/Firm Relative } \\
\text { Debt Ratio }\end{array}$ & 0.000 & 0.000 & 2.213 & 0.766 & $2.212^{* * *}$ & $0.766^{\text {*k* }}$ \\
\hline $\begin{array}{l}\text { CEO Pension } \\
\text { Benefits }\end{array}$ & 0.000 & 0.000 & 0.142 & 0.036 & $0.142^{* * *}$ & $0.036^{* * *}$ \\
\hline $\begin{array}{l}\text { CEO Deferred } \\
\text { Compensation }\end{array}$ & 0.000 & 0.000 & 0.100 & 0.050 & $0.100^{* * *}$ & $0.050^{\text {*** }}$ \\
\hline $\begin{array}{l}\text { CEO Vega/Delta } \\
\text { Ratio }\end{array}$ & 0.355 & 0.236 & 0.447 & 0.372 & $0.091^{* * *}$ & $0.137^{\text {*** }}$ \\
\hline CEO Age & 54.6 & 54 & 56.4 & 56 & $1.9^{\text {k** }}$ & $2^{* * *}$ \\
\hline CEO Tenure & 7.5 & 5 & 7.1 & 5 & $-0.3^{* *}$ & 0 \\
\hline $\begin{array}{l}\text { Independent } \\
\text { Directors }\end{array}$ & 0.771 & 0.800 & 0.806 & 0.800 & $0.036^{* * *}$ & 0.000 \\
\hline $\begin{array}{l}\text { Institutional } \\
\text { Ownership }\end{array}$ & 0.758 & 0.795 & 0.758 & 0.795 & 0.000 & 0.000 \\
\hline $\begin{array}{l}\text { Total Assets } \\
\text { (Smillion) }\end{array}$ & 3,951 & 1,281 & 18,718 & 4,757 & $14,767^{* * *}$ & $3,476^{* * *}$ \\
\hline $\begin{array}{l}\text { Market-to-Book } \\
\text { Ratio }\end{array}$ & 1.437 & 1.133 & 1.111 & 0.927 & $-0.326^{* * *}$ & $-0.206^{* * *}$ \\
\hline Profitability & 0.105 & 0.106 & 0.117 & 0.114 & $0.013^{* * *}$ & $0.008^{* * *}$ \\
\hline Asset Tangibility & 0.210 & 0.116 & 0.271 & 0.184 & $0.062^{* * *}$ & $0.068^{\text {*** }}$ \\
\hline Depreciation & 0.044 & 0.036 & 0.035 & 0.032 & $-0.008^{* * *}$ & $-0.005^{\text {*** }}$ \\
\hline $\mathrm{R} \& \mathrm{D}$ & 0.035 & 0 & 0.013 & 0 & $-0.022^{* * *}$ & 0 \\
\hline $\begin{array}{l}\text { R\&D Missing } \\
\text { Dummy }\end{array}$ & 0.586 & 1 & 0.478 & 0 & $-0.108^{* * *}$ & $-1^{* * *}$ \\
\hline $\begin{array}{l}\text { Dividend Payer } \\
\text { Dummy }\end{array}$ & 0.346 & 0 & 0.708 & 1 & $0.362^{* * *}$ & $1^{* * *}$ \\
\hline $\begin{array}{l}{ }^{* * *} \text { Significant at the } 0 \\
{ }^{* *} \text { Significant at the } \\
{ }^{*} \text { Significant at the }\end{array}$ & & & & & & \\
\hline
\end{tabular}

leverage and CEO's inside debt, CEO's inside debt might have an impact on the dynamics of firm leverage.

We plot the firm's leverage ratio and the CEO's inside debt ratio together during our sample period (Figure 1b), as well as during CEO Tenure (Figure 1c). During our sample period from 2007 to 2013, the two variables closely track each other, rising in 2008 and 2011 and declining in all other years. Again, this demonstrates the presence of time-related factors that affect the 


\section{Table III. Correlations}

This table presents the Pearson's correlation of the firm's debt ratio and the CEO's inside debt ratio in time $t$ and $t-1$, as well as their changes.

\begin{tabular}{|c|c|c|c|c|c|c|c|c|c|c|c|c|}
\hline & & (1) & $(2)$ & $(3)$ & $(4)$ & (5) & (6) & $(7)$ & (8) & $(9)$ & $(10)$ & (11) \\
\hline (1) & $\begin{array}{l}\text { Firm Market Debt } \\
\text { Ratio }_{t}\end{array}$ & & & & & & & & & & & \\
\hline (2) & $\begin{array}{l}\text { CEO Inside Debt } \\
\text { Ratio }_{t}\end{array}$ & 0.24 & & & & & & & & & & \\
\hline (3) & CEO Pension ${ }_{t}$ & 0.21 & 0.82 & & & & & & & & & \\
\hline (4) & $\begin{array}{l}\text { CEO Deferred } \\
\text { Comp.t }\end{array}$ & 0.13 & 0.59 & 0.03 & & & & & & & & \\
\hline (5) & $\begin{array}{l}\text { Firm Market Debt } \\
\text { Ratio } t_{-1}\end{array}$ & 0.86 & 0.19 & 0.18 & 0.09 & & & & & & & \\
\hline (6) & $\begin{array}{l}\text { CEO Inside Debt } \\
\text { Ratio }_{t-1}\end{array}$ & 0.20 & 0.82 & 0.70 & 0.46 & 0.25 & & & & & & \\
\hline (7) & CEO Pension ${ }_{t-1}$ & 0.17 & 0.70 & 0.84 & 0.03 & 0.21 & 0.83 & & & & & \\
\hline (8) & $\begin{array}{l}\text { CEO Deferred } \\
\text { Comp } t_{-1}\end{array}$ & 0.11 & 0.47 & 0.03 & 0.78 & 0.13 & 0.59 & 0.04 & & & & \\
\hline (9) & $\begin{array}{c}\Delta \text { Firm Market } \\
\text { Debt Ratio }{ }_{t}\end{array}$ & 0.08 & 0.33 & 0.24 & 0.24 & -0.08 & -0.27 & -0.20 & -0.19 & & & \\
\hline (10) & $\begin{array}{l}\triangle \mathrm{CEO} \text { Inside Debt } \\
\text { Ratio }_{t}\end{array}$ & 0.27 & 0.10 & 0.07 & 0.07 & -0.25 & -0.08 & -0.07 & -0.05 & 0.31 & & \\
\hline (11) & $\triangle \mathrm{CEO}$ Pension $_{t}$ & 0.07 & 0.26 & 0.31 & 0.01 & -0.06 & -0.20 & -0.25 & -0.01 & 0.78 & 0.26 & \\
\hline (12) & $\begin{array}{l}\triangle C E O \text { Deferred } \\
\text { Comp }_{t}\end{array}$ & 0.04 & 0.21 & 0.00 & 0.37 & -0.06 & -0.18 & -0.02 & -0.29 & 0.64 & 0.18 & 0.02 \\
\hline
\end{tabular}

two variables in similar ways. When plotted against CEO Tenure, interestingly, the two variables exhibit a discernible mirror image contrast. In the first nine years of $C E O$ Tenure, firm leverage generally declines, while CEO's inside debt holdings increases. Starting in the tenth year of a CEO's tenure, the trend reverses for both variables. What drives these patterns could be related to a CEO's risk aversion, but is outside the scope of this study. What it indicates about the relation between CEO's inside debt holdings and firm leverage is of greater interest. A firm tends to make upward (downward) adjustments in financial leverage when its CEO's inside debt holdings decline (rise).

Extending the probe, we examine the adjustment in firm leverage in four subsamples based on the lagged CEO's inside debt ratio. Firms with zero inside debt, firms whose inside debt ratio is nonzero, but less than 0.15 , between 0.15 and 0.30 , and above 0.30 . There are 3,165 , $3,183,1,506$, and 2,161 observations in these subsamples, respectively. The cutoffs are chosen so that the low inside debt group has about the same size as the zero inside debt group, and the intermediate inside debt group is of the same width for the range of the inside debt ratio as the low inside debt group. Partitioning firms with nonzero inside debt into terciles yields qualitatively similar results. Shown in Table IV, zero inside debt firms are different from other firms using inside debt and, on average, they essentially do not adjust their capital structures. Firms that use inside debt exhibit a monotonic declining trend in firm's leverage ratio changes as the lagged CEO's inside debt ratio gets higher. Firms with low CEO's inside debt adjust their firm's leverage ratios upwardly by 1.5 percentage points, those with intermediate inside debt adjust firm's leverage ratios upwardly by 0.8 percentage points, and those with high inside debt adjust their firm's leverage ratios downward by 1.0 percentage points. The difference in the firm's 


\section{Table IV. CEO's Inside Debt and Subsequent Change in Firm's Debt Ratio}

This table reports the mean and median changes in the firm's debt ratio given different levels of lagged CEO's inside debt in the full sample. The CEO's inside debt ratio is classified into four levels: zero, low (lower than 0.15), intermediate (higher than 0.15, but lower than 0.30), and high (higher than 0.30). The differences in mean and median changes in the firm's debt ratio and their statistical significance based on two-sample mean and median tests are reported.

\begin{tabular}{|c|c|c|c|c|c|c|}
\hline \multirow[b]{2}{*}{$\Delta$ Firm Debt Ratio $_{t}$} & \multicolumn{6}{|c|}{ CEO Inside Debt $_{t-1}$} \\
\hline & $\begin{array}{l}\text { Zero } \\
{[0,0]}\end{array}$ & $\begin{array}{c}\text { Low } \\
(0,0.15]\end{array}$ & $\begin{array}{c}\text { Intermediate } \\
(0.15,0.30]\end{array}$ & $\begin{array}{c}\text { High } \\
(0.30,1)\end{array}$ & High - Low & $p$-Value \\
\hline $\bar{N}$ & 3,165 & 3,183 & 1,506 & 2,161 & & \\
\hline Mean & 0.002 & 0.015 & 0.008 & -0.010 & $-0.025^{* * *}$ & $<0.001$ \\
\hline Median & -0.001 & 0.000 & -0.002 & -0.013 & $-0.013^{* * *}$ & $<0.001$ \\
\hline
\end{tabular}

leverage adjustment between high and low inside debt firms is statistically significant at the $1 \%$ level. The comparison of median firm's leverage adjustments yields a similar pattern. These comparisons again suggest a negative relation between CEO's inside debt and firm leverage, and invite more in-depth examination of this relation.

\section{CEO's Inside Debt and Level of Firm Leverage: Dynamic Panel Model}

We use Model (2) to conduct the multivariate analyses. This model not only accounts for a large array of control variables that are found to impact firm leverage, including observable firm characteristics, corporate governance, and CEO characteristics, but also controls for unobserved firm and time heterogeneity using lagged firm leverage and fixed firm and time effects. The baseline estimator is the Elsas and Florysiak (2015) DPF method that is designed to deal with unbalanced large- $\mathrm{N}$, short- $\mathrm{T}$, panel data with a fractional dependent variable.

The estimates are reported in Column (1) of Table V. First, the coefficient of lagged firm's debt ratio is 0.751 implying a SOA of 0.249 consistent with Elsas and Florysiak (2015). Lagged CEO's inside debt ratio, presented near the bottom, loads negatively with a coefficient of -0.079 that is statistically significant at the $1 \%$ level. This confirms the presence of a negative relation between CEO's inside debt and firm leverage, even after controlling for all other factors. A one-standard deviation increase $(0.212)$ in the CEO's inside debt ratio corresponds to a decline of 1.7 percentage points in the firm's market debt ratio. This effect is not large, but it is also not trivial considering the mean (median) annual leverage adjustment is $0.4(-0.2)$ percentage points.

Except for $R \& D$, all of the firm characteristic variables significantly impact the market debt ratio. We find that board independence is negatively related to firm leverage, which is not consistent with the idea that a more independent board encourages excessively conservative CEOs to take on more debt. However, since all boards have a majority of Independent Directors after SOX, it has become less clear how Independent Directors may impact CEO monitoring. Consistent with Liao et al. (2015), Institutional Ownership receives a positive and statistically significant coefficient indicating that shareholders encourage the use of debt. CEO Age is also negatively associated with the firm's debt ratio consistent with the notion that older CEOs become more risk averse (Serfling, 2014). The coefficient estimate for CEO Tenure is not statistically 


\section{Table V. CEO's Inside Debt and Firm Leverage}

This table presents the estimations of the dynamic panel model of capital structure. The dependent variable is the firm's market debt ratio. Independent variables include the conventional set of firm characteristics that impact tax benefits and bankruptcy costs including firm size, the Market-to-Book Ratio, Profitability, Asset Tangibility, Depreciation, $R \& D$, missing $R \& D$ dummy, and the industry median leverage. Variables that represent shareholders' interests include the percentage of outside directors on a board and Institutional Ownership and CEO characteristics including age, tenure, the Vega/Delta ratio, and the inside debt ratio. Column (2) includes a dummy variable that is equal to one if the CEO does not hold inside debt in the previous year. The models are estimated using the Elsas and Florysiak (2015) dynamic panel dependent variable (DPF) estimator. Column (3) reports the second-stage DPF estimates when the state-level growth of the older population ( 65 years or older) and the industry median CEO's inside debt ratio are used as the instruments for the CEO's inside debt ratio. Column (4) provides estimates using the Blundell-Bond (1998) system GMM estimator. Standard errors are reported in the parentheses.

\begin{tabular}{|c|c|c|c|c|}
\hline & $\begin{array}{c}\text { (1) } \\
\text { DPF }\end{array}$ & $\begin{array}{c}(2) \\
\text { DPF }\end{array}$ & $\begin{array}{c}(3) \\
\text { Two-Stage DPF }\end{array}$ & $\begin{array}{l}(4) \\
\text { GMM }\end{array}$ \\
\hline Firm Debt Ratio $t-1$ & $\begin{array}{l}0.751^{\text {*** }} \\
(0.009)\end{array}$ & $\begin{array}{l}0.752^{* * *} \\
(0.009)\end{array}$ & $\begin{array}{l}0.739^{* * *} \\
(0.009)\end{array}$ & $\begin{array}{l}0.762^{* * * *} \\
(0.038)\end{array}$ \\
\hline $\operatorname{Ln}\left(\right.$ Assets $\left._{t-1}\right)$ & $\begin{array}{l}0.032^{* * *} \\
(0.005)\end{array}$ & $\begin{array}{l}0.031^{\text {*** }} \\
(0.005)\end{array}$ & $\begin{array}{l}0.032^{\text {*** }} \\
(0.005)\end{array}$ & $\begin{array}{r}-0.007 \\
(0.008)\end{array}$ \\
\hline Market-to-Book Ratio ${ }_{t-1}$ & $\begin{array}{l}0.031^{\text {*** }} \\
(0.003)\end{array}$ & $\begin{array}{l}0.031^{\text {*** }} \\
(0.003)\end{array}$ & $\begin{array}{l}0.031^{\text {*** }} \\
(0.003)\end{array}$ & $\begin{array}{r}-0.013^{*} \\
(0.007)\end{array}$ \\
\hline Profitability $_{t-1}$ & $\begin{array}{l}0.079^{* * *} \\
(0.021)\end{array}$ & $\begin{array}{l}0.079^{* * *} \\
(0.021)\end{array}$ & $\begin{array}{l}0.080^{\text {*** }} \\
0.022\end{array}$ & $\begin{array}{c}0.067 \\
(0.071)\end{array}$ \\
\hline Asset 'langibility $_{t-1}$ & $\begin{array}{l}0.153^{* * *} \\
(0.033)\end{array}$ & $\begin{array}{l}0.153^{* * *} \\
(0.033)\end{array}$ & $\begin{array}{l}0.136^{* * *} \\
(0.033)\end{array}$ & $\begin{array}{r}-0.062 \\
(0.070)\end{array}$ \\
\hline Depreciation $_{t-1}$ & $\begin{array}{c}-0.858^{* * *} \\
(0.129)\end{array}$ & $\begin{array}{c}-0.857^{* k *} \\
(0.129)\end{array}$ & $\begin{array}{c}-0.827^{* * *} \\
(0.131)\end{array}$ & $\begin{array}{c}0.452 \\
(0.586)\end{array}$ \\
\hline${\mathrm{R} \& \mathrm{D}_{t-1}}$ & $\begin{array}{c}0.009 \\
(0.067)\end{array}$ & $\begin{array}{c}0.009 \\
(0.067)\end{array}$ & $\begin{array}{c}-0.002 \\
(0.067)\end{array}$ & $\begin{array}{r}-0.025 \\
(0.243)\end{array}$ \\
\hline R\&D Missing Dummy -1 & $\begin{array}{r}-0.019 \\
(0.012)\end{array}$ & $\begin{array}{l}-0.019 \\
(0.012)\end{array}$ & $\begin{array}{c}-0.019 \\
(0.012)\end{array}$ & $\begin{array}{r}-0.048 \\
(0.035)\end{array}$ \\
\hline Industry Median Debt Ratio & $\begin{array}{l}0.050^{* * *} \\
(0.010)\end{array}$ & $\begin{array}{l}0.051^{\text {*** }} \\
(0.010)\end{array}$ & $\begin{array}{l}0.053^{* * *} \\
(0.010)\end{array}$ & $\begin{array}{c}0.037 \\
(0.099)\end{array}$ \\
\hline Independent Directors $_{t-1}$ & $\begin{array}{c}-0.038^{* *} \\
(0.018)\end{array}$ & $\begin{array}{c}-0.038^{* *} \\
(0.018)\end{array}$ & $\begin{array}{c}-0.037^{* *} \\
(0.018)\end{array}$ & $\begin{array}{r}-0.082 \\
(0.059)\end{array}$ \\
\hline Institutional Ownership ${ }_{t-1}$ & $\begin{array}{l}0.080^{* * *} \\
(0.010)\end{array}$ & $\begin{array}{l}0.080^{* * *} \\
(0.010)\end{array}$ & $\begin{array}{l}0.072^{\text {*** }} \\
(0.010)\end{array}$ & $\begin{array}{c}0.051 \\
(0.048)\end{array}$ \\
\hline Ln(CEO Age) & $\begin{array}{c}-0.068^{* * *} \\
(0.000)\end{array}$ & $\begin{array}{c}-0.068^{k * *} \\
(0.000)\end{array}$ & $\begin{array}{c}-0.002^{* * *} \\
(0.000)\end{array}$ & $\begin{array}{c}0.092 \\
(0.109)\end{array}$ \\
\hline Ln(1+CEO Tenure $)$ & $\begin{array}{c}0.002 \\
(0.002)\end{array}$ & $\begin{array}{c}0.002 \\
(0.002)\end{array}$ & $\begin{array}{c}0.001^{* *} \\
(0.000)\end{array}$ & $\begin{array}{r}-0.014 \\
(0.014)\end{array}$ \\
\hline CEO Vega/Delta Ratio ${ }_{t-1}$ & $\begin{array}{c}-0.004^{* * k} \\
(0.001)\end{array}$ & $\begin{array}{c}-0.005^{\text {k** }} \\
(0.001)\end{array}$ & $\begin{array}{c}-0.005^{\text {*** }} \\
(0.001)\end{array}$ & $\begin{array}{r}-0.001 \\
(0.003)\end{array}$ \\
\hline CEO Inside Debt Ratio $t_{-1}$ & $\begin{array}{c}-0.079^{* * *} \\
(0.011)\end{array}$ & $\begin{array}{c}-0.081^{* * *} \\
(0.012)\end{array}$ & $\begin{array}{c}-0.095^{\text {*** }} \\
(0.018)\end{array}$ & $\begin{array}{c}-0.075^{* *} \\
(0.034)\end{array}$ \\
\hline Zero CEO Debt Ratio Dummy & & $\begin{array}{c}-0.004^{* * *} \\
(0.001)\end{array}$ & & $\begin{array}{c}-0.096^{* * *} \\
(0.032)\end{array}$ \\
\hline Constant & $\begin{array}{c}0.016 \\
(0.017)\end{array}$ & $\begin{array}{c}0.021 \\
(0.017)\end{array}$ & $\begin{array}{c}0.000 \\
(0.017)\end{array}$ & $\begin{array}{r}-0.113 \\
(0.427)\end{array}$ \\
\hline
\end{tabular}


Table V. CEO's Inside Debt and Firm Leverage (Continued)

\begin{tabular}{|c|c|c|c|c|}
\hline & $\begin{array}{l}(1) \\
\text { DPF }\end{array}$ & $\begin{array}{l}(2) \\
\text { DPF }\end{array}$ & $\begin{array}{c}(3) \\
\text { Two-Stage DPF }\end{array}$ & $\begin{array}{c}(4) \\
\text { GMM }\end{array}$ \\
\hline Year Dummies & Yes & Yes & Yes & Yes \\
\hline Wald $\chi^{2}$ & 33,817 & 33,825 & 32,870 & 2,332 \\
\hline Prob $>\chi^{2}$ & 0.000 & 0.000 & 0.000 & 0.000 \\
\hline $\begin{array}{c}{ }^{* * *} \text { Significant at } t \\
{ }^{* *} \text { Significant at } \\
{ }^{*} \text { Significant at }\end{array}$ & & & & \\
\hline
\end{tabular}

different from zero. This is not surprising given the inverse $\mathrm{V}$-shape pattern between CEO Tenure and firm leverage as shown in Figure 1(c). Surprisingly, the CEO Vega/Delta ratio is negatively related to the firm's market debt ratio indicating that CEOs who have equity-type compensation that is more sensitive to the volatility of the firm's stock price and/or less sensitive to the change in the firm's stock price tend to avoid the use of debt financing. ${ }^{12}$

In Column (2), we consider firms that offer no debt-type compensation to their CEOs separately by including a dummy variable that is equal to one for firms offering zero inside debt, and zero otherwise. The dummy variable receives a negative coefficient of -0.004 that is statistically significant at the $1 \%$ level indicating that these firms do use less debt financing, but the difference is fairly small. All other results remain nearly the same.

Then, we directly address the potential endogeneity concerns pertaining to CEO's inside debt even after controlling for firm and CEO characteristics, unobservable firm and time heterogeneity, and the lagged independent variable. Our approach is to use growth of the older population in the state where the firm is headquartered and the median CEO's inside debt ratio of the industry as instruments. ${ }^{13}$ Specifically, we run an OLS regression of the CEO's inside debt ratio on the two instrument variables and all other control variables used in Model (2), and then use the predicted value of the CEO's inside debt ratio in the previous period to replace the CEO's inside debt ratio in Column (1). We then estimate the second-stage model using the DPF estimator. The results are presented in Column (3). The CEO's inside debt ratio obtains a coefficient of -0.095 , statistically significant at the $1 \%$ level. Thus, after controlling for potential endogeneity, we find that CEO's inside debt negatively affects the firm's leverage ratio.

As a robustness check, we also apply the widely used Blundell-Bond (1998) system GMM estimator to Model (2) and report the estimates in Column (4). This approach uses a vector of lagged levels and differences of the dependent variable to address the problem of the persistent regressor. It also confers the convenience of using similar instruments for endogenous variables. ${ }^{14}$ Although most control variables do not have coefficients that are significantly different from zero,

\footnotetext{
${ }^{12}$ This is inconsistent with the notion that Vega encourages risk taking (Guay, 1999; Coles et al., 2006). Notwithstanding, Cassell et al. (2012) obtain a similar negative and statistically significant relationship between the CEO Vega/Delta Ratio and the firm's book leverage (see their table VI).

${ }^{13}$ We conduct the Finlay, Magnusson, and Schaffer (2013) weak instrument tests to check the validity of these instruments in the DPF (Tobit) context. We obtain a 95\% confidence interval of $[-0.117,0.029]$ for the coefficient of CEO's inside debt ratio (the coefficient estimate is -0.095 ), and an overidentification test $J$-statistic of 2.10 with a $p$-value of 0.147 . In addition, both instruments have a fairly strong correlation with the CEO's inside debt ratio ( -0.15 and 0.41 , respectively), and the first-stage regression yields an adjusted $R^{2}$ of 0.275 . All of these results indicate that our instruments are valid. Please find the first-stage estimation in Appendix B.

${ }^{14}$ We use lags 2 to 5 of levels and differences as instruments and also treat CEO's inside debt, Independent Directors, Institutional Ownership, and the CEO VegaLelta Ratio as endogenous.
} 
two main results hold unchanged. First, the SOA is 0.238 . In addition, the CEO's inside debt ratio loads negatively with a coefficient of -0.075 . Moreover, the zero CEO's inside debt dummy receives a statistically significant, negative coefficient of a larger magnitude, -0.096 . Thus, the system GMM estimator produces results consistent with the DPF estimates.

\section{E. Shareholders' Desired Leverage}

Morellec et al. (2012) hold that self-interested managers have target leverage that is below the shareholders' desired level. Liao et al. (2015) verify this claim empirically. To the extent that CEO's inside debt holdings escalate the shareholders-manager divergence in risk preference, the positive (negative) coefficient on Institutional Ownership (CEO's inside debt ratio) we have obtained above is consistent with their findings. Institutional shareholders would like to see higher firm leverage, while CEOs with inside debt tend to keep firm leverage at a lower level. These incongruous incentives have profound implications for the target leverage estimation. Since managers are hired by shareholders to run the company, the level of leverage that maximizes shareholder wealth should be the target leverage. In other words, a firm should move its financial leverage toward the shareholders' desired level. This level is different from the predicted value in Model (2) where CEOs' private interests could distort capital structure choices. In fact, the target leverage to maximize shareholder wealth can be achieved only if the CEO's interests are perfectly aligned with shareholders'. Based on this idea, we estimate the shareholders' desired leverage using the coefficients in Column (1) of Table V, assuming institutional shareholders own all outstanding shares and CEOs are compensated with equity, but no inside debt. When Institutional Ownership is one and CEO's inside debt is zero, shareholders have a strong voice in the firm's policies and CEOs are subject to a lower level of (or ideally no) conservatism. The latter is true as equity-type compensation encourages risk taking and debt-type compensation that could worsen managerial conservatism is nonexistent. Then it is most likely that CEOs' capital structure decisions are consistent with what shareholders desire, and our ad hoc estimates reflect the shareholders' desired leverage.

Appendix C reports the summary statistics of our estimated shareholders' desired leverage and deviation from this target leverage. The mean (median) of this measure is $0.316(0.275)$, $0.035(0.039)$ higher than the actual market debt ratio. Relative to the shareholders' desired leverage, 8,054 firm-year observations are underlevered and merely 1,961 are overlevered. The predominance of underlevered firms is evidence of the divergence of incentives between the CEOs and shareholders, consistent with our conjecture that excessively conservative CEOs intentionally keep firm leverage low. ${ }^{15}$

\section{F. CEO's Inside Debt and Capital Structure Adjustments}

As shown in Liao et al. (2015), the sign of leverage deviation could influence the CEO's attitude toward capital structure adjustments. Since the CEO's desired leverage is lower than that of shareholders, both the CEO and the shareholders would like to lower firm leverage when leverage is above the shareholders' desired level. If leverage is below the shareholders' desired level, however, the shareholders would want to boost leverage to the desired level, while the CEO

\footnotetext{
${ }^{15}$ On average, firms are underlevered due to managerial conservatism. Individual firms, though, might witness temporary overshoots in leverage due to "shocks," such as an unexpected market price decline. The overlevered situation may also emerge if a firm decides to issue a large amount of debt, rather than selling small amounts of debt in several issues, when expecting growing market capitalization in the future. The overlevered situation may last for quite a long time if it is the result of financial distress as the firm may find it difficult to raise equity capital and reduce debt.
} 


\section{Table VI. CEO's Inside Debt and Subsequent Change in Firm's Debt Ratio Given Leverage Deviations}

'This table presents the mean and median changes in the firm's debt ratio given different levels of lagged CEO's inside debt in the subsamples of underlevered (Panel A) or overlevered (Panel B) firms, respectively. The CEO's inside debt ratio is classified into four levels: zero, low (lower than 0.15), intermediate (higher than 0.15 , but lower than 0.30), and high (higher than 0.30). The differences in mean and median changes in the firm's debt ratio and their statistical significance based on two-sample mean and median tests are reported.

\begin{tabular}{|c|c|c|c|c|c|c|}
\hline \multirow[b]{2}{*}{$\Delta$ Firm Debt Ratio ${ }_{t}$} & \multicolumn{6}{|c|}{ CEO Inside $\mathrm{Debt}_{t-1}$} \\
\hline & $\begin{array}{l}\text { Zero } \\
{[0,0]}\end{array}$ & $\begin{array}{c}\text { Low } \\
(0,0.15]\end{array}$ & $\begin{array}{c}\text { Intermediate } \\
(0.15,0.30]\end{array}$ & $\begin{array}{c}\text { High } \\
(0.30,1)\end{array}$ & High - Low & $p$-Value \\
\hline \multicolumn{7}{|c|}{ Panel A. Underlevered Firms } \\
\hline$N$ & 2,282 & 2,603 & 1,305 & 1,864 & & \\
\hline Mean & 0.027 & 0.028 & 0.018 & 0.007 & $-0.021^{* * *}$ & $<0.001$ \\
\hline Median & 0.000 & 0.006 & 0.001 & -0.007 & $-0.013^{* * *}$ & $<0.001$ \\
\hline \multicolumn{7}{|c|}{ Panel B. Overlevered Firms } \\
\hline$N$ & 883 & 580 & 201 & 297 & & \\
\hline Mean & -0.062 & -0.045 & -0.056 & -0.120 & $-0.075^{* * *}$ & $<0.001$ \\
\hline Median & -0.054 & -0.039 & -0.050 & -0.100 & $-0.061^{* * *}$ & $<0.001$ \\
\hline
\end{tabular}

may not. To the extent that inside debt holding aggravates the CEO's excessive conservatism, higher inside debt holding would give rise to faster adjustments toward the target leverage in the overlevered domain, but impede adjustments in the underlevered domain.

To test this hypothesis, we first partition the underlevered firms and overlevered firms separately into four subsamples of firms with zero, low, intermediate, and high levels of the lagged CEO's inside debt ratio, and then consider their leverage adjustment patterns in the subsequent year. Table VI presents the results. Overall, underlevered firms adjust leverage upward, overlevered firms adjust leverage downward, and the magnitude of the adjustment is dependent upon the CEO's inside debt holdings. On average, in the underlevered domain (Panel A), firms with low CEO's inside debt holdings adjust their market debt ratio upward by 2.8 percentage points, firms with intermediate CEO's inside debt holdings adjust by 1.8 percentage points, and those with high CEO's inside debt holdings adjust by merely 0.7 percentage points. The medians present a similar pattern. The differences in mean and median adjustments across the high and low CEO's inside debt subsamples are statistically significant at the $1 \%$ level. In the overlevered domain (Panel B), firms with low, intermediate, and high CEO's inside debt holdings adjust their debt ratio downward by $4.5,5.6$, and 12.0 percentage points, respectively. In short, CEO's inside debt holding speeds up leverage adjustments from above the shareholders' desired level, but impedes adjustments from below the shareholders' desired level.

A rigorous examination of the effect of CEO's inside debt on the firm's leverage adjustments is based on Model (3), where target leverage is the shareholders' desired level and the capital structure SOA is allowed to vary with CEO's inside debt and other factors. As discussed in Section II.A, control variables include certain firm characteristics, CEO characteristics, and corporate governance measures. We estimate the model in the full sample and then in the subsamples of 


\section{Table VII. CEO's Inside Debt and Capital Structure Adjustments}

The table reports the results from estimating the model: $\Delta L_{i t}=\left(\lambda_{0}+\lambda_{1} E_{i, t-1}+\lambda_{2} C_{i, t-1}\right) D_{i t}+\varepsilon_{i t}$ in the full sample and two subsamples: firms where the market debt ratio is above the shareholders' desired level ("Overlevered") or below this level ("Underlevered"). In the model, $D_{i t}$ denotes the deviation from the shareholders' desired market leverage of firm $i$ at the start of period $t . \mathrm{E}_{i, l-1}$ represents the CEO's inside debt ratio. $C_{i, t-1}$ are a set of control variables including the CEO Vega/Delta Ratio, age, tenure, outside directors, Institutional Ownership, firm size, and dividend payer indicator, as well as year dummies (coefficients not reported). $\lambda_{1}$ and $\lambda_{2}$ are coefficients on the interaction items between CEO leverage and firm leverage deviation, and those between the control variables and the firm leverage deviation, respectively. A dummy variable that indicates zero CEO's inside debt is also considered in Specification (2). Bootstrapped standard errors are reported in brackets.

\begin{tabular}{|c|c|c|c|c|c|c|}
\hline & \multicolumn{2}{|c|}{$\begin{array}{l}\text { Full Sample } \\
(n=10,015)\end{array}$} & \multicolumn{2}{|c|}{$\begin{array}{l}\text { Overlevered } \\
(n=1,961)\end{array}$} & \multicolumn{2}{|c|}{$\begin{array}{l}\text { Underlevered } \\
(n=8,054)\end{array}$} \\
\hline & (1) & (2) & (1) & (2) & (1) & (2) \\
\hline CEO Inside Debt Ratio $t_{-1}$ & $\begin{array}{c}0.069 \\
(0.138)\end{array}$ & $\begin{array}{c}0.113 \\
(0.141)\end{array}$ & $\begin{array}{l}1.942^{* * *} \\
(0.371)\end{array}$ & $\begin{array}{l}2.018^{* * *} \\
(0.446)\end{array}$ & $\begin{array}{c}-0.272^{* * *} \\
(0.085)\end{array}$ & $\begin{array}{c}-0.289^{* * *} \\
(0.091)\end{array}$ \\
\hline Zero CEO Inside Debt $_{t-1}$ & & $\begin{array}{l}0.057 \\
(0.064)\end{array}$ & & $\begin{array}{c}0.067 \\
(0.184)\end{array}$ & & $\begin{array}{c}-0.027 \\
(0.064)\end{array}$ \\
\hline CEO Vega/Delta Ratio $t_{-1}$ & $\begin{array}{c}0.023 \\
(0.017)\end{array}$ & $\begin{array}{c}0.024 \\
(0.017)\end{array}$ & $\begin{array}{c}0.004 \\
(0.042)\end{array}$ & $\begin{array}{c}0.004 \\
(0.043)\end{array}$ & $\begin{array}{c}0.010 \\
(0.019)\end{array}$ & $\begin{array}{c}0.009 \\
(0.018)\end{array}$ \\
\hline $\mathrm{CEO} \mathrm{Age}{ }_{t}$ & $\begin{array}{c}0.000 \\
(0.004)\end{array}$ & $\begin{array}{c}0.001 \\
(0.004)\end{array}$ & $\begin{array}{c}0.006 \\
(0.011)\end{array}$ & $\begin{array}{c}0.006 \\
(0.011)\end{array}$ & $\begin{array}{r}-0.002 \\
(0.004)\end{array}$ & $\begin{array}{c}-0.002 \\
(0.004)\end{array}$ \\
\hline CEO Tenure $_{t}$ & $\begin{array}{c}0.004 \\
(0.004)\end{array}$ & $\begin{array}{l}0.004 \\
(0.004)\end{array}$ & $\begin{array}{c}-0.006 \\
(0.011)\end{array}$ & $\begin{array}{r}-0.006 \\
(0.011)\end{array}$ & $\begin{array}{c}0.006 \\
(0.004)\end{array}$ & $\begin{array}{c}0.006 \\
(0.003)^{*}\end{array}$ \\
\hline Independent Directors $t_{-1}$ & $\begin{array}{c}0.023 \\
(0.182)\end{array}$ & $\begin{array}{l}0.030 \\
(0.182)\end{array}$ & $\begin{array}{c}0.696 \\
(0.791)\end{array}$ & $\begin{array}{c}0.731 \\
(0.791)\end{array}$ & $\begin{array}{c}-0.048 \\
(0.173)\end{array}$ & $\begin{array}{c}-0.050 \\
(0.173)\end{array}$ \\
\hline Institutional Ownership $t_{-1}$ & $\begin{array}{l}0.590^{* * *} \\
(0.125)\end{array}$ & $\begin{array}{l}0.603^{* * *} \\
(0.125)\end{array}$ & $\begin{array}{c}-0.536 \\
(0.350)\end{array}$ & $\begin{array}{c}-0.520 \\
(0.353)\end{array}$ & $\begin{array}{l}0.703^{* * *} \\
(0.118)\end{array}$ & $\begin{array}{l}0.697^{* * *} \\
(0.117)\end{array}$ \\
\hline $\log (\text { Assets })_{t-1}$ & $\begin{array}{c}-0.030^{* *} \\
(0.013)\end{array}$ & $\begin{array}{r}-0.026^{*} \\
(0.014)\end{array}$ & $\begin{array}{c}-0.061 \\
(0.043)\end{array}$ & $\begin{array}{c}-0.057 \\
(0.046)\end{array}$ & $\begin{array}{c}-0.014 \\
(0.012)\end{array}$ & $\begin{array}{c}-0.016 \\
(0.013)\end{array}$ \\
\hline Dividend Payer $_{t-1}$ & $\begin{array}{c}-0.354^{* * *} \\
(0.058)\end{array}$ & $\begin{array}{c}-0.343^{* * *} \\
(0.059)\end{array}$ & $\begin{array}{c}-0.011 \\
(0.153)\end{array}$ & $\begin{array}{r}-0.004 \\
(0.153)\end{array}$ & $\begin{array}{r}-0.093^{*} \\
(0.052)\end{array}$ & $\begin{array}{r}-0.098^{*} \\
(0.053)\end{array}$ \\
\hline Constant & $\begin{array}{c}-0.041 \\
(0.260)\end{array}$ & $\begin{array}{c}-0.126 \\
(0.282)\end{array}$ & $\begin{array}{c}0.934 \\
(0.918)\end{array}$ & $\begin{array}{c}0.817 \\
(0.979)\end{array}$ & $\begin{array}{r}-0.386 \\
(0.238)\end{array}$ & $\begin{array}{c}-0.345 \\
(0.259)\end{array}$ \\
\hline $\begin{array}{l}\text { Year Dummies } \\
R^{2}\end{array}$ & $\begin{array}{c}\text { Yes } \\
0.176\end{array}$ & $\begin{array}{c}\text { Yes } \\
0.176\end{array}$ & $\begin{array}{c}\text { Yes } \\
0.274\end{array}$ & $\begin{array}{c}\text { Yes } \\
0.274\end{array}$ & $\begin{array}{c}\text { Yes } \\
0.165\end{array}$ & $\begin{array}{c}\text { Yes } \\
0.165\end{array}$ \\
\hline $\begin{array}{l}{ }^{+*+} \text { Significant at the } 0.01 \mathrm{lev} \\
{ }^{* *} \text { Significant at the } 0.05 \mathrm{lev} \\
{ }^{*} \text { Significant at the } 0.10 \mathrm{lev}\end{array}$ & & & & & & \\
\hline
\end{tabular}

overlevered and underlevered firms separately. We also consider a slightly different specification, Specification (2), where firms with zero CEO's inside debt holdings are treated specially with a dummy variable. Table VII reports the results.

In the full sample, CEO's inside debt receives statistically insignificant coefficient estimates regardless of the specification, but these near-zero coefficients conceal the real effect of CEO's inside debt as demonstrated below. In the overlevered subsample, the coefficient of the CEO's inside debt ratio is 1.94 , statistically significant at the $1 \%$ level. This indicates that higher CEO's inside debt holdings are associated with faster adjustments toward the shareholders' desired level. This association is economically very large. A one-standard deviation 
increase $(0.212)$ in the CEO's inside debt ratio would accelerate the SOA by about 0.40 , holding all else equal. In the underlevered domain, however, the CEO's inside debt ratio obtains statistically significant, negative coefficients of approximately -0.28 , indicating that a onestandard deviation increase in the CEO's inside debt ratio slows down the SOA by nearly 0.06 , still an economically large effect. In Specification (2), the results are qualitatively unchanged. The opposite signs of the CEO's inside debt coefficient estimates in the over- and underlevered domains are consistent with our expectations that CEO's inside debt holdings exacerbate their excessive conservatism. Consequentially, CEOs are eager to reduce the use of debt when the firm is overlevered, but reluctant to increase the use of debt when the firm is underlevered.

\section{G. Optimal CEO's Inside Debt Holdings for Capital Structure Decisions}

Debt-type compensation for managers alleviates the conflict of interest between managers and debtholders and lowers the agency cost of debt, but exacerbates the divergence in attitude toward risk between managers and shareholders. Identifying this tradeoff may help in determining an inside debt level that is optimal for capital structure decisions and CEO's inside debt holdings that facilitate the fastest capital structure adjustment toward the shareholders' desired level.

Given the positive correlation between the CEO's inside debt ratio and the firm's debt ratio, the CEO/Firm Relative Debt Ratio defined as the CEO's inside debt ratio divided by the firm's market debt ratio, is relevant for answering this question. ${ }^{16}$ Using the relative ratio rather than the absolute CEO's inside debt ratio also helps answer the question whether an equity bias in executive compensation is beneficial (Edmans and Liu, 2011). Our strategy is to estimate the capital structure SOA in subsamples based on different levels of CEO/Firm Relative Debt Ratio and find at what level we obtain the greatest SOA. We first single out the 3,210 firm-year observations with zero CEO's inside debt as the first subsample. We then divide firms having a positive CEO/Firm Relative Debt Ratio that is below the median of 0.295 into two subsamples, $(0,0.10]$, and $(0.10,0.295]$. Finally, the remaining observations having above median CEO/Firm Relative Debt Ratio are partitioned into five quantiles. These cutoffs give rise to seven subsamples that include six with roughly equal numbers of nonzero relative debt ratio observations. The SOA is estimated using Model (1), where leverage deviation is that from the shareholders' desired level.

The estimated SOAs are presented in Table VIII. In Panel A, the SOA is 0.764 for zero inside debt firms, and jumps to 1.091 for firms with relative debt ratios below 0.1 . The SOA declines to 0.960 in the next subsample and keeps declining monotonically to 0.083 in the last subsample with the highest CEO/Firm Relative Debt Ratio. The SOA peaks when the CEO's inside debt ratio is around $10 \%$ of the Firm Market Debt Ratio.

The CEO-shareholders divergence of risk preference is more pronounced when upward adjustments are needed. Thus, we repeat the above SOA comparisons in the subsamples of underlevered firms. The cutoffs for forming the subsamples are the same. Panel B of Table VIII reports that the estimated SOA exhibits an identical pattern where it rises considerably from the zero inside debt subsample to the $(0,0.10]$ domain, and then monotonically declines as the CEO/Firm Relative Debt Ratio increases. Thus, with regard to capital structure adjustments, we find the optimal CEO's inside debt holdings are very low, at around $10 \%$ of the firm's market debt-to-capital ratio.

\footnotetext{
${ }^{16}$ The CEO/Firm Relative Debt Ratio is set to its median value, 0.295 , in case both the numerator and denominator are zero. The results do not change if we exclude observations with a zero CEO's inside debt ratio and a zero firm's debt ratio.
} 


\section{Table VIII. Capital Structure SOAs Given Different Relative CEO/Firm Debt Ratios}

This table presents the estimated speeds of adjustment (SOAs) in subsamples defined by the relative CEO/firm debt ratio. The SOA is estimated in the second-stage regression $\Delta L_{i t}=\lambda D_{i t}+\varepsilon_{i t}$, where $\Delta L_{i t}$ is the change in firm $i$. leverage ratio in period $t . D_{i t}$ represents the deviation from the shareholders' desired leverage of firm $i$ at the start of period $t$, and $\lambda$ is the SOA. The model is estimated using OLS. Firms with zero CEO's inside debt constitute a subsample. Firms with nonzero CEO's inside debt are classified into seven roughly equal-sized subsamples based on the value of the CEO's inside debt ratio/firm debt ratio. Number of observations and $R^{2}$ of the regression for each subsample are also reported.

\section{CEO Inside Debt Ratio/Firm Debt Ratio}

\begin{tabular}{|c|c|c|c|c|c|c|c|c|}
\hline & {$[0,0]$} & $(0,0.100]$ & $(0.100,0.295]$ & $(0.295,0.569]$ & $(0.569,0.900]$ & $(0.900,1.343]$ & $(1.343,2.301]$ & $(2.301, \infty)$ \\
\hline \multicolumn{9}{|c|}{ Panel A. Full Sample } \\
\hline Nobs & 3.210 & 871 & 925 & 1.003 & 1,001 & 1.002 & 1,001 & 1,002 \\
\hline Estimated SOA & 0.764 & 1.091 & 0.960 & 0.823 & 0.783 & 0.609 & 0.310 & 0.083 \\
\hline$R^{2}$ & 0.122 & 0.196 & 0.149 & 0.136 & 0.112 & 0.098 & 0.061 & -0.031 \\
\hline \multicolumn{9}{|c|}{ Panel B. Underlevered Firms } \\
\hline Nobs & 2.289 & 599 & 683 & 800 & 850 & 913 & 950 & 970 \\
\hline Estimated SOA & 0.522 & 0.874 & 0.830 & 0.714 & 0.704 & 0.535 & 0.263 & -0.030 \\
\hline$R^{2}$ & 0.015 & 0.057 & 0.061 & 0.073 & 0.063 & 0.055 & 0.046 & -0.027 \\
\hline
\end{tabular}




\section{Table IX. CEO's Inside Debt and Firm Book Leverage}

This table presents the estimation of the dynamic panel model of capital structure. The dependent variable is the firm's book debt ratio. Independent variables include the conventional set of firm characteristics that impact tax benefits and bankruptcy costs including firm size, Market-to-Book Ratio, Profitability, Asset Tangibility, Depreciation, $R \& D$, missing $R \& D$ dummy, and the industry median leverage. Variables that represent shareholders' interests include the percentage of outside directors on a board and Institutional Ownership and CEO characteristics including age, tenure, the Vega/Delta ratio, and the inside debt ratio. Column (2) includes a dummy variable that is equal to one if the CEO does not hold inside debt in the previous year. The models are estimated using the Elsas and Florysiak (2015) dynamic panel dependent variable (DPF) estimator. Column (3) provides the second-stage DPF estimates when the state-level growth of the older population ( 65 years or older) and the industry median CEO's inside debt ratio are used as the instruments for the CEO's inside debt ratio. Standard errors are reported in the parentheses. Wald test chi-squares of the model are reported at the bottom.

\begin{tabular}{|c|c|c|c|}
\hline & $\begin{array}{c}(1) \\
\text { FPD }\end{array}$ & $\begin{array}{c}(2) \\
\text { FPD }\end{array}$ & $\begin{array}{c}(3) \\
\text { Two-Stage FPD }\end{array}$ \\
\hline Firm Debt Ratio $t-1$ & $\begin{array}{l}0.767^{\text {*** }} \\
(0.022)\end{array}$ & $\begin{array}{l}0.763^{\text {*** }} \\
(0.022)\end{array}$ & $\begin{array}{l}0.753^{\text {*** }} \\
(0.021)\end{array}$ \\
\hline $\operatorname{Ln}\left(\right.$ Assets $\left._{t-1}\right)$ & $\begin{array}{l}0.015^{\text {*k* }} \\
(0.005)\end{array}$ & $\begin{array}{l}0.014^{\text {*k* }} \\
(0.005)\end{array}$ & $\begin{array}{l}0.014^{\text {*** }} \\
(0.005)\end{array}$ \\
\hline Market-to-Book Ratio $t-1$ & $\begin{array}{l}0.014^{* * *} \\
(0.002)\end{array}$ & $\begin{array}{l}0.014^{* * *} \\
(0.002)\end{array}$ & $\begin{array}{l}0.014^{\text {*** }} \\
(0.002)\end{array}$ \\
\hline Profitability $_{t-1}$ & $\begin{array}{c}0.005 \\
(0.021)\end{array}$ & $\begin{array}{c}0.004 \\
(0.021)\end{array}$ & $\begin{array}{c}0.003 \\
(0.021)\end{array}$ \\
\hline Asset Tangibility $_{t-1}$ & $\begin{array}{l}0.154^{* * *} \\
(0.031)\end{array}$ & $\begin{array}{l}0.154^{\text {*** }} \\
(0.031)\end{array}$ & $\begin{array}{l}0.148^{\text {*** }} \\
(0.031)\end{array}$ \\
\hline Depreciation $_{t-1}$ & $\begin{array}{c}-0.266^{* *} \\
(0.122)\end{array}$ & $\begin{array}{c}-0.263^{* *} \\
(0.122)\end{array}$ & $\begin{array}{r}-0.237^{*} \\
(0.123)\end{array}$ \\
\hline $\mathrm{R} \& \mathrm{D}_{t-1}$ & $\begin{array}{c}-0.285^{* * *} \\
(0.063)\end{array}$ & $\begin{array}{c}-0.286^{* * *} \\
(0.063)\end{array}$ & $\begin{array}{l}-0.293^{* * *} \\
(0.063)\end{array}$ \\
\hline R\&D Missing Dummy $t-1$ & $\begin{array}{r}-0.021^{*} \\
(0.011)\end{array}$ & $\begin{array}{r}-0.021^{*} \\
(0.011)\end{array}$ & $\begin{array}{r}-0.021^{*} \\
(0.011)\end{array}$ \\
\hline Industry Median Debt Ratio & $\begin{array}{l}0.072^{* * *} \\
(0.012)\end{array}$ & $\begin{array}{l}0.074^{* * *} \\
(0.012)\end{array}$ & $\begin{array}{l}0.072^{* * *} \\
(0.012)\end{array}$ \\
\hline Independent Directors $t_{-1}$ & $\begin{array}{c}-0.034^{* *} \\
(0.017)\end{array}$ & $\begin{array}{c}-0.034^{* *} \\
(0.017)\end{array}$ & $\begin{array}{r}-0.033 \\
(0.017)\end{array}$ \\
\hline Institutional Ownership ${ }_{t-1}$ & $\begin{array}{l}0.029^{* * *} \\
(0.010)\end{array}$ & $\begin{array}{l}0.028^{* * *} \\
(0.010)\end{array}$ & $\begin{array}{l}0.022^{* *} \\
(0.010)\end{array}$ \\
\hline $\mathrm{Ln}(\mathrm{CEO}$ Age $)$ & $\begin{array}{r}-0.016 \\
(0.020)\end{array}$ & $\begin{array}{c}-0.015^{\text {*** }} \\
(0.020)\end{array}$ & $\begin{array}{c}-0.005 \\
(0.004)\end{array}$ \\
\hline Ln(1+CEO Tenure $)$ & $\begin{array}{c}0.002 \\
(0.002)\end{array}$ & $\begin{array}{c}0.002 \\
(0.002)\end{array}$ & $\begin{array}{r}0.008^{*} \\
(0.004)\end{array}$ \\
\hline CEO Vega/Delta Ratio $t-1$ & $\begin{array}{r}-0.002^{*} \\
(0.001)\end{array}$ & $\begin{array}{r}-0.002^{*} \\
(0.001)\end{array}$ & $\begin{array}{r}-0.002^{*} \\
(0.001)\end{array}$ \\
\hline CEO Inside Debt Ratio ${ }_{t-1}$ & $\begin{array}{r}-0.017^{*} \\
(0.010)\end{array}$ & $\begin{array}{r}-0.019^{*} \\
(0.010)\end{array}$ & $\begin{array}{l}-0.064^{* * *} \\
(0.023)\end{array}$ \\
\hline Zero CEO Debt Ratio Dummy & & $\begin{array}{c}-0.008^{* *} \\
(0.003)\end{array}$ & \\
\hline Constant & $\begin{array}{c}0.056 \\
(0.053)\end{array}$ & $\begin{array}{c}0.071 \\
(0.054)\end{array}$ & $\begin{array}{r}-0.041^{*} \\
(0.022)\end{array}$ \\
\hline
\end{tabular}


Table IX. CEO's Inside Debt and Firm Book Leverage (Continued)

\begin{tabular}{|c|c|c|c|}
\hline & $\begin{array}{l}(1) \\
\text { FPD }\end{array}$ & $\begin{array}{c}(2) \\
\text { FPD }\end{array}$ & $\begin{array}{c}(3) \\
\text { Two-Stage FPD }\end{array}$ \\
\hline Year Dummies & Yes & Yes & Yes \\
\hline Wald $\chi^{2}$ & 23,095 & 22,854 & 21,850 \\
\hline Prob $>\chi^{2}$ & 0.000 & 0.000 & 0.000 \\
\hline \multicolumn{4}{|c|}{$\begin{array}{l}{ }^{* *} \text { S Significant at the } 0.01 \text { level. } \\
{ }^{*+} \text { Significant at the } 0.05 \text { level. }\end{array}$} \\
\hline
\end{tabular}

This result echoes Edmans and Liu's (2011) insight that an equity bias is often optimal. Edmans and Liu (2011) envision that even when managers are risk neutral and excessive conservatism is irrelevant, an equity bias is desired to induce effort. In the presence of managerial conservatism, a greater equity bias would be beneficial as its risk-shifting effect encourages managers to take risks.

A caveat is in order. While our investigation is only from the angle of capital structure decisions, debt-type compensation also affects other aspects of corporate policies as documented in the literature, which would, in turn, impact firm value. In particular, pensions are offered for purposes other than providing incentives, such as building manager-firm "bonding" (Sundaram and Yermack, 2007), mitigating shirking to avoid costly losses in retirement pay due to early termination (Lazear, 1979), and enabling firms more control over retirement payouts (Lazear, 1979, 1983). Thus, we should not view the inside debt level that is conducive to the optimal capital structure decision as equivalent to the optimal level that maximizes firm value.

\section{H. Robustness Check with Book Leverage}

All of our results thus far are based on the market debt ratio. Some of the literature (Faulkender et al., 2012) uses the book debt ratio arguing that book leverage is more likely to be under the control of managers. We examine the effect of the CEO's inside debt ratio on the level and SOA of firm book leverage in Tables IX and X, respectively. In Table IX, where the results from estimating Model (2) are reported, lagged firm's debt ratio receives highly significant coefficient estimates of around 0.76 , while the lagged CEO's inside debt ratio receives statistically significant, negative coefficient estimates between -0.017 and -0.064 , regardless of the model specification (i.e., exclusion or inclusion of the zero inside debt dummy) or estimation approach. In Table X, CEO's inside debt commands positive coefficients that are marginally statistically significant in the overlevered subsample, but negative and statistically significant coefficients in the underlevered subsample. The results are qualitatively similar to those based on market debt ratio.

\section{Which Matters, Pensions or Other Deferred Compensation?}

Between pension plans and other deferred compensation, the former resembles unsecured debt more closely as supplemental executive retirement plans (SERPs) are often unfunded and unsecured. In contrast, with some special arrangements, deferred compensation may be invested in equity and withdrawn flexibly before retirement. Thus, the incentive effect of pensions may be stronger than that of deferred compensation. Consistent with this, Anantharaman et al. (2014) 


\section{Table X. CEO's Inside Debt and Adjustments of Book Leverage}

The table reports the results from estimating the model: $\Delta L_{i t}=\left(\lambda_{0}+\lambda_{1} E_{i, t-1}+\lambda_{2} C_{i, t-1}\right) D_{i t}+\varepsilon_{i t}$ in the full sample and two subsamples: firms where the book leverage ratio is above the shareholders' desired level ("Overlevered"), or below this level ("Underlevered"). In the model, $D_{i t}$ denotes the deviation from the shareholders' desired book leverage of firm $i$ at the start of period $t . E_{i, t-1}$ represents the CEO's inside debt ratio. $C_{i, t-1}$ are a set of control variables including the CEO Vega/Delta Ratio, age, tenure, outside directors, Institutional Ownership, firm size, and dividend payer indicator, as well as year dummies (coefficients not reported). $\lambda_{1}$ and $\lambda_{2}$ are coefficients on the interaction items between CEO leverage and firm leverage deviation, and those between control variables and firm leverage deviation, respectively. A dummy variable that indicates zero CEO's inside debt is also considered in Specification (2). Bootstrapped standard errors are reported in brackets.

\begin{tabular}{|c|c|c|c|c|c|c|}
\hline & \multicolumn{2}{|c|}{$\begin{array}{l}\text { Full Sample } \\
(n=10,015)\end{array}$} & \multicolumn{2}{|c|}{$\begin{array}{l}\text { Overlevered } \\
(n=1,961)\end{array}$} & \multicolumn{2}{|c|}{$\begin{array}{l}\text { Underlevered } \\
(n=8,054)\end{array}$} \\
\hline & (1) & (2) & (1) & $(2)$ & $(1)$ & (2) \\
\hline CEO Inside Debt Ratio $t_{-1}$ & $\begin{array}{c}0.097 \\
(0.206)\end{array}$ & $\begin{array}{c}0.088 \\
(0.214)\end{array}$ & $\begin{array}{c}0.424 \\
(0.325)\end{array}$ & $\begin{array}{r}0.557^{*} \\
(0.337)\end{array}$ & $\begin{array}{r}-0.363^{*} \\
(0.195)\end{array}$ & $\begin{array}{c}-0.518^{* *} \\
(0.210)\end{array}$ \\
\hline Zero CEO Inside Debt $_{t-1}$ & & $\begin{array}{l}(0.010) \\
(0.078)\end{array}$ & & $\begin{array}{c}0.145 \\
(0.109)\end{array}$ & & $\begin{array}{c}-0.175 \\
(0.111)\end{array}$ \\
\hline CEO Vega/Delta Ratio $t-1$ & $\begin{array}{c}-0.003 \\
(0.018)\end{array}$ & $\begin{array}{c}-0.003 \\
(0.018)\end{array}$ & $\begin{array}{r}-0.016 \\
(0.025)\end{array}$ & $\begin{array}{r}-0.016 \\
(0.025)\end{array}$ & $\begin{array}{c}0.004 \\
(0.024)\end{array}$ & $\begin{array}{c}0.002 \\
(0.024)\end{array}$ \\
\hline $\mathrm{CEO} \mathrm{Age}_{t}$ & $\begin{array}{c}-0.001 \\
(0.005)\end{array}$ & $\begin{array}{c}-0.001 \\
(0.005)\end{array}$ & $\begin{array}{c}-0.002 \\
(0.008)\end{array}$ & $\begin{array}{c}-0.002 \\
(0.008)\end{array}$ & $\begin{array}{c}-0.001 \\
(0.007)\end{array}$ & $\begin{array}{c}-0.002 \\
(0.007)\end{array}$ \\
\hline CEO Tenure $_{t}$ & $\begin{array}{c}-0.003 \\
(0.005)\end{array}$ & $\begin{array}{c}-0.003 \\
(0.005)\end{array}$ & $\begin{array}{c}-0.008 \\
(0.007)\end{array}$ & $\begin{array}{r}-0.007 \\
(0.007)\end{array}$ & $\begin{array}{r}-0.002 \\
(0.006)\end{array}$ & $\begin{array}{c}-0.001 \\
(0.006)\end{array}$ \\
\hline Independent Directors $t_{-1}$ & $\begin{array}{r}0.538^{*} \\
(0.301)\end{array}$ & $\begin{array}{r}0.535^{*} \\
(0.301)\end{array}$ & $\begin{array}{c}0.520 \\
(0.443)\end{array}$ & $\begin{array}{c}0.563 \\
(0.442)\end{array}$ & $\begin{array}{c}0.453 \\
(0.406)\end{array}$ & $\begin{array}{c}0.411 \\
(0.403)\end{array}$ \\
\hline Institutional Ownership $t_{-1}$ & $\begin{array}{c}0.106 \\
(0.185)\end{array}$ & $\begin{array}{c}0.104 \\
(0.185)\end{array}$ & $\begin{array}{c}-0.424 \\
(0.317)\end{array}$ & $\begin{array}{c}-0.417 \\
(0.317)\end{array}$ & $\begin{array}{l}0.548^{* * *} \\
(0.189)\end{array}$ & $\begin{array}{l}0.518^{* * *} \\
(0.190)\end{array}$ \\
\hline $\log (\text { Assets })_{t-1}$ & $\begin{array}{c}-0.073^{* * *} \\
(0.023)\end{array}$ & $\begin{array}{c}-0.073^{* * *} \\
(0.024)\end{array}$ & $\begin{array}{c}-0.090^{* *} \\
(0.042)\end{array}$ & $\begin{array}{r}-0.079^{*} \\
(0.043)\end{array}$ & $\begin{array}{c}-0.060^{* *} \\
(0.024)\end{array}$ & $\begin{array}{c}-0.072^{* * *} \\
(0.024)\end{array}$ \\
\hline Dividend Payer $_{t-1}$ & $\begin{array}{c}-0.027 \\
(0.068)\end{array}$ & $\begin{array}{c}-0.028 \\
(0.068)\end{array}$ & $\begin{array}{c}-0.068 \\
(0.092)\end{array}$ & $\begin{array}{r}-0.045 \\
(0.091)\end{array}$ & $\begin{array}{c}0.080 \\
(0.097)\end{array}$ & $\begin{array}{c}0.063 \\
(0.098)\end{array}$ \\
\hline Constant & $\begin{array}{c}0.553 \\
(0.401)\end{array}$ & $\begin{array}{c}0.569 \\
(0.414)\end{array}$ & $\begin{array}{r}1.191^{*} \\
(0.641)\end{array}$ & $\begin{array}{c}0.987 \\
(0.647)\end{array}$ & $\begin{array}{c}0.066 \\
(0.520)\end{array}$ & $\begin{array}{c}0.385 \\
(0.549)\end{array}$ \\
\hline $\begin{array}{l}\text { Year Dummies } \\
R^{2}\end{array}$ & $\begin{array}{c}\text { Yes } \\
0.074\end{array}$ & $\begin{array}{c}\text { Yes } \\
0.074\end{array}$ & $\begin{array}{l}\text { Yes } \\
0.072\end{array}$ & $\begin{array}{l}\text { Yes } \\
0.073\end{array}$ & $\begin{array}{c}\text { Yes } \\
0.061\end{array}$ & $\begin{array}{c}\text { Yes } \\
0.062\end{array}$ \\
\hline $25 \mathrm{lev}$ & & & & & & \\
\hline
\end{tabular}

find that higher debt-type compensation leads to lower promised yield and fewer covenants in corporate loans, but this effect is caused entirely by benefits accrued under SERPs. It is of interest to examine whether the debt-reduction effect of inside debt is attributable solely to pensions, but not to deferred compensation.

We investigate this question first in Model (1) by using the pension to total incentive compensation ratio and the deferred compensation to total incentive compensation ratio in place of the total CEO's inside debt ratio. Both ratios load negatively with a coefficient that is of similar size (about -0.08 ) and are statistically significant at the 1\% level. Thus, pensions or deferred compensation have similar effects on the level of financial leverage. Then, we estimate Model 
(2) using the two component inside debt ratios and find, similar to the results in Table VII, that both ratios load negatively (positively) in the regression for the underlevered (overlevered) subsample. In either subsample, the coefficient of pension to the incentive compensation ratio is greater in magnitude than that of the deferred compensation to the incentive compensation ratio, and is of greater statistical significance. Thus, as both pensions and deferred compensation encourage faster capital structure adjustments in an overlevered situation and impede adjustments in an underlevered situation, the effect of pensions is somewhat stronger than that of deferred compensation. ${ }^{17}$

\section{Conclusions}

Since Jensen and Meckling (1976), it has been argued that both equity and debt compensation should be included in managerial compensation contracts in order to incentivize managers to take both shareholders' and debtholders' interests into account when making financing and investment decisions. Edmans and Liu (2011) theoretically derive an optimal compensation contract that uses equity compensation as a solution to the manager-shareholder agency conflict, as it induces managerial effort, and debt compensation as a solution to the shareholder-debtholder agency conflict, as it incentivizes managers to avoid risk shifting that transfers wealth from debtholders to shareholders.

In this article, we investigate the impact of CEO's inside debt holdings on capital structure dynamics. We find that the CEO's inside debt ratio, measured using both pension plans and deferred compensation data, is negatively associated with firm leverage. We then estimate shareholders' desired leverage where shareholder wealth is maximized and examine how CEO's inside debt affects the firm's SOA toward this level for overlevered and underlevered firms. We find that greater CEO's inside debt holdings spur an overlevered firm to adjust capital structure at a more rapid pace toward its shareholders' desired level, but impedes such adjustments for an underlevered fïrm. Finally, estimating the capital structure SOAs in subsamples of firms having different levels of CEO's inside debt ratios, we find that the CEO's inside debt ratio that is conducive to optimal capital structure dynamics is around $10 \%$ of the firm's market debt ratio.

This article is the first to empirically investigate the impact CEO's inside debt has on capital structure dynamics. Our findings indicate that debt-type compensation exacerbates managers' excessive conservatism that leads to lower than optimal use of debt and slower capital structure adjustments toward shareholders' desired level, which is detrimental to shareholders' interests.

Since managers, even without inside debt, tend to be more risk averse than shareholders, they are aligned with debtholder interests to some extent. A main purpose served by debttype compensation is to align the interest of managers with debtholders, but only at the expense of shareholders as it increases the divergence in risk preferences between managers and shareholders. Thus, the optimal compensation structure is unlikely to be similar to the firm's capital structure as Jensen and Meckling (1976) conjecture, and a large equity bias (Edmans and Liu, 2011) is probably necessary. This finding has profound implications concerning the design of executive compensation packages. While pensions and deferred compensation may serve good purposes, firms should also take note of their adverse effects on managers' risk attitudes.

\footnotetext{
${ }^{17}$ These results are available upon request.
} 
Appendix A: Variable Definitions

\begin{tabular}{|c|c|}
\hline Variable & Definition \\
\hline Firm Market Debt Ratio & $\begin{array}{l}\text { Total book debt/(total book debt }+ \text { market equity), where total } \\
\text { debt is the sum of long-term debt and notes payable, and } \\
\text { market equity is found as the product of the number of } \\
\text { shares outstanding and share price at the fiscal year-end. }\end{array}$ \\
\hline Firm Book Debt Ratio & $\begin{array}{l}\text { Total book debt/(total book debt }+ \text { book equity), where total } \\
\text { debt is the sum of long-term debt and notes payable. }\end{array}$ \\
\hline CEO Inside Debt Ratio & $\begin{array}{l}\text { CEO's inside debt holdings, including pension and deferred } \\
\text { compensation, divided by total compensation. Inside debt } \\
\text { holdings are the sum of the present value of accumulated } \\
\text { pension benefits and deferred compensation. CEO total } \\
\text { compensation also includes the value of stock and stock } \\
\text { options. Stock value is calculated by multiplying the number } \\
\text { of shares held (including restricted shares) by the stock price } \\
\text { at the firm's fiscal year-end. Following Cassel et al. (2012), } \\
\text { we apply the Black-Scholes (1973) option valuation formula } \\
\text { for each individual tranche of options held by the CEO and } \\
\text { sum the tranche value to a grand total. }\end{array}$ \\
\hline CEO Debt/Equity Ratio & $\begin{array}{l}\text { CEO's debt-type compensation divided by equity-type } \\
\text { compensation. }\end{array}$ \\
\hline CEO/Firm Relative Debt Ratio & $\begin{array}{l}\text { CEO's inside debt ratio/firm debt ratio. It is set to the median } \\
\text { value }(0.295) \text { in case both CEO's debt ratio and firm's debt } \\
\text { ratio are zero, and set to the } 99 \text { th percentile value }(46.48) \text { if } \\
\text { the CEO's debt ratio is positive, while firm's debt ratio is } \\
\text { zero. }\end{array}$ \\
\hline CEO Pension Benefits & CEO pension benefits divided by total compensation. \\
\hline CEO Deferred Compensation & CEO deferred compensation divided by total compensation. \\
\hline CEO Vega/Delta Ratio & $\begin{array}{l}\text { The ratio of the Vega (the sensitivity of the value of the CEO's } \\
\text { accumulated equity-based compensation to a } 1 \% \text { change in } \\
\text { the volatility of stock prices) to the Delta (the sensitivity of } \\
\text { the value of the CEO's accumulated equity-based } \\
\text { compensation to a } 1 \% \text { change in the stock price) (Grant, } \\
\text { Markarian, and Parbonetti, 2009). Vega and Delta are } \\
\text { calculated following Core and Guay (2002). }\end{array}$ \\
\hline CEO Age & The age of the CEO. \\
\hline CEO Tenure & The tenure of the CEO. \\
\hline Independent Directors & The percentage of independent directors on the board. \\
\hline Institutional Ownership & $\begin{array}{l}\text { The percentage of common shares owned by institutional } \\
\text { investors. }\end{array}$ \\
\hline Total Assets (\$million) & Total assets in million 2005 constant dollars. \\
\hline Market-to-Book Ratio & $\begin{array}{l}\text { (Market value of common equity }+ \text { book value of debt }+ \\
\text { preferred stock - deferred tax and investment tax } \\
\text { credit)/book value of assets. }\end{array}$ \\
\hline Profitability & Operating income before depreciation divided by total assets. \\
\hline Asset Tangibility & Property, plant, and equipment divided by total assets. \\
\hline Depreciation & Depreciation and amortization divided by total assets. \\
\hline $\mathrm{R} \& \mathrm{D}$ & $\mathrm{R} \& \mathrm{D}$ divided by total assets. Set to zero if missing. \\
\hline R\&D Missing Dummy & Equal to one if R\&D is not reported, and zero otherwise. \\
\hline Dividend Payer Dummy & Equal to one for dividend payers, and zero for nonpayers. \\
\hline
\end{tabular}




\section{Appendix B: First-Stage Estimation for Two-Stage DPF}

This independent variable is the CEO's inside debt ratio. The OLS estimation is reported in this table. The predicted value is lagged before being used in the second-stage DPF estimation as the instrument for lagged CEO Inside Debt Ratio.

\begin{tabular}{|c|c|c|c|}
\hline Independent Variable & Coefficient & $S E$ & $t$-Value \\
\hline Firm Debt Ratio ${ }_{t-1}$ & $0.055^{\text {*** }}$ & 0.011 & 5.003 \\
\hline $\operatorname{Ln}\left(\right.$ assets $\left._{t-1}\right)$ & $0.023^{* * *}$ & 0.001 & 17.972 \\
\hline Market-to-Book Ratio ${ }_{t-1}$ & $-0.009^{* * *}$ & 0.002 & -3.739 \\
\hline Profitability $_{t-1}$ & 0.007 & 0.022 & 0.301 \\
\hline Asset Tangibility ${ }_{t-1}$ & $0.039^{* k *}$ & 0.010 & 3.974 \\
\hline Depreciation $_{t-1}$ & $-0.307^{* * *}$ & 0.076 & -4.066 \\
\hline $\mathrm{R} \& \mathrm{D}_{t-1}$ & $-0.146^{* * *}$ & 0.045 & -3.261 \\
\hline R\&D Missing Dummy D $_{t-1}$ & $0.009^{* *}$ & 0.004 & 2.002 \\
\hline Industry Median Debt Ratio & $-0.110^{* * *}$ & 0.018 & -6.071 \\
\hline Independent Directors $t_{-1}$ & $0.164^{* * *}$ & 0.019 & 8.572 \\
\hline Institutional Ownership $t_{t-1}$ & $-0.022^{* *}$ & 0.010 & -2.308 \\
\hline $\operatorname{Ln}(C E O$ Age $)$ & $0.004^{* * *}$ & 0.000 & 13.888 \\
\hline Ln( $1+$ CEO Tenure $)$ & $-0.001^{* * *}$ & 0.000 & -2.748 \\
\hline CEO Vega/Delta Ratio ${ }_{t-1}$ & $0.014^{* * *}$ & 0.001 & 11.212 \\
\hline \multicolumn{4}{|c|}{ Old Population (Age 65 or Above) Change 2000-2010 } \\
\hline in State & $-0.044^{* * *}$ & 0.004 & -10.314 \\
\hline Industry Median CEO Inside Debt Ratio $t_{-1}$ & $0.614^{* * *}$ & 0.021 & 29.946 \\
\hline Constant & $-0.136^{* * *}$ & 0.034 & -4.071 \\
\hline Adjusted $R^{2}$ & 0.275 & & \\
\hline
\end{tabular}

${ }^{* * *}$ Significant at the 0.01 level.

${ }^{*}$ Significant at the 0.05 level.

\section{Appendix C: Shareholders' Desired Beverage}

This table presents the summary statistics of the estimated shareholders' desired leverage and the deviation from this target leverage at the start of the period. The shareholders' desired leverage is estimated based on Model (2), using coefficients from Column (1) of Table V, and assuming the Institutional Ownership is one and CEO's inside debt ratio is zero. For details, please see Section III.E.

\begin{tabular}{lccccc}
\hline \hline Variable & Mean & Median & SD & 1st percentile & 99th percentile \\
\hline $\begin{array}{l}\text { Shareholders' desired debt } \\
\quad \text { ratio }\end{array}$ & 0.316 & 0.275 & 0.196 & 0 & 0.845 \\
$\begin{array}{l}\text { Firm Market Debt } \\
\quad \begin{array}{l}\text { Ratio } \\
\text { Deviation from } \\
\text { shareholders' desired } \\
\text { leverage }\end{array}\end{array}$ & 0.281 & 0.235 & 0.217 & 0 & 0.134 \\
\hline \hline
\end{tabular}




\section{References}

Amihud, Y. and B. Lev, 1981, "Risk Reduction as a Managerial Motive for Conglomerate Mergers," Bell Journal of Economics 12, 605-617.

Anantharaman, D., V.W. Fang, and G. Gong, 2014, "Inside Debt and the Design of Corporate Debt Contracts," Management Science 60, 1260-1280.

Bebchuk, L.A. and R.J. Jackson, Jr., 2005, “Executive Pensions," Journal of Corporation Law 30, 823-855.

Berger, P., E. Ofek, and D. Yermack, 1997, "Managerial Entrenchment and Capital Structure Decisions," Journal of Finance 52, 1411-1438.

Black, F. and M. Scholes, 1973, "The Pricing of Options and Corporate Liabilities," Journal of Political Economy 81, 637-654.

Blundell, R. and S. Bond, 1998, "Initial Conditions and Moment Restrictions in Dynamic Panel Data Models," Journal of Econometrics 87, 115-143.

Cassell, C.A., S.X. Huang, J.M. Sanchez, and M.D. Stuart, 2012, "Seeking Safety: The Relation between CEO Inside Debt Holdings and the Riskiness of Firm Investment and Financial Policies," Journal of Financial Economics 102, 588-610.

Coles, J.L., N.D. Daniel, and L. Naveen, 2006, "Managerial Incentives and Risk-Taking," Journal of Financial Economics 79, 431-468.

Cook, D. and T. Tang, 2010, "Macroeconomic Conditions and Capital Structure Adjustment Speed," Journal of Corporate Finance 16, 73-87.

Core, J. and W. Guay, 2002, "Estimating the Value of Employee Stock Option Portfolios and Their Sensitivities to Price and Volatility," Journal of Accounting Research 40, 613-630.

Dang, V.A., M. Kim, and Y. Shin, 2015, "In Search of Robust Methods for Dynamic Panel Data Models in Empirical Corporate Finance," Journal of Banking and Finance 53, 84-98.

DeAngelo, H. and R. Roll, 2015, "How Stable are Corporate Capitals?" Journal of Finance 70, 373- 418.

Edmans, A. and Q. Liu, 2011, "Inside Debt," Review of Finance 15, 75-102.

Elsas, R. and D. Florysiak, 2015, "Dynamic Capital Structure Adjustment and the Impact of Fractional Dependent Variables," Journal of Financial and Quantitative Analysis 50, 1105-1133.

Fama, E.F. and K.R. French, 2002, "Testing Tradeoff and Pecking Order Predictions About Dividends and Debt," Review of Financial Studies 15, 1-33.

Faulkender, M.W., M.J. Flannery, K.W. Hankins, and J.M. Smith, 2012, "Cash Flows and Leverage Adjustments," Journal of Financial Economics 103, 632-646.

Finlay, K., L.M. Magnusson, and M.E. Schaffer, 2013, Weakiv: Weak-Instrument-Robust Tests and Confidence Intervals for Instrumental-Variable (IV) Estimation of Linear, Probit and Tobit Models. Available at: http://ideas.repec.org/c/boc/bocode/s457684.html. Retrieved Oct. 18, 2016.

Flannery, M.J. and K.W. Hankins, 2013, "Estimating Dynamic Panels in Corporate Finance," Journal of Corporate Finance 19, 1-19.

Flannery, M.J. and K.P. Rangan, 2006, "Partial Adjustment toward Target Capital Structures," Journal of Financial Economics 79, 469-506.

Gormley, T. and D.A Masta, 2016, "Playing it Safe? Managerial Preferences, Risk, and Agency Conflicts," Journal of Financial Economics 122, 431-455. 
Grant, J., G. Markarian, and A. Parbonetti, 2009, "CEO Risk-Related Incentives and Income Smoothing," Contemporary Accounting Research 26, 1029-1065.

Guay, W., 1999, "The Sensitivity of CEO Wealth to Equity Risk: An Analysis of the Magnitude and Determinants," Journal of Financial Economics 53, 43-71.

Hirshleifer, D. and A.V. Thakor, 1992, "Managerial Conservatism, Project Choice, and Debt," Review of Financial Studies 5, 437-470.

Holmström, B., 1999, "Managerial Incentive Problems: A Dynamic Perspective," Review of Economic Studies 66, 169-182.

Hovakimian, A. and G. Li, 2012, "Is the Partial Adjustment Model a Useful Tool for Capital Structure Research?" Review of Finance 16, 733-754.

Huang, R. and J. Ritter, 2009, "Testing Theories of Capital Structure and Estimating the Speed of Adjustment," Journal of Financial and Quantitative Analysis 44, 237-271.

Iliev, P. and I. Welch, 2010, "Reconciling Estimates of the Speed of Adjustment of Leverage Ratios," UCLA Working paper.

Jalilvand, A. and R.S. Harris, 1984, "Corporate Behavior in Adjusting to Capital Structure and Dividend Targets: An Econometric Study," Journal of Finance 39, 127-145.

Jensen, M.C. and W.H. Meckling, 1976, "Theory of the Firm: Managerial Behavior, Agency Costs and Ownership Structure," Journal of Financial Economics 3, 305-360.

Klein, W.A. and J.C. Coffee, Jr., 1996, Business Organization and Finance: Legal and Economic Principles, 6th Ed., Westbury, NY, Foundation Press, 266-267.

Korajczyk, R. and A. Levy, 2003, "Capital Structure Choice: Macroeconomic Conditions and Financial Constraints," Journal of Financial Economics 68, 75-109.

Lazear, E., 1979, "Why Is There Mandatory Retirement?" Journal of Political Economy 87, 1261-1284.

Lazear, E., 1983, "Pensions as Severance Pay," in Z. Bodie, J. Shoven, and D. Wise, Eds. Financial Aspects of the United States Pension System, Chicago, IL, University of Chicago Press, 57-85.

Lemmon, M.L., M.R. Roberts, and J.F. Zender, 2008, "Back to the Beginning: Persistence and the CrossSection of Corporate Capital Structure," Journal of Finance 63, 1575-1608.

Liao, L., T. Mukherjee, and W. Wang, 2015, "Corporate Governance and Capital Structure Dynamics: An Empirical Study," Journal of Financial Research 48, 169-191.

Liu, Y., D.C. Mauer, and Y. Zhang, 2014, “Firm Cash Holdings and CEO Inside Debt," Journal of Banking of Finance 42, 83-100.

Loudermilk, M.S., 2007, "Estimation of Fractional Dependent Variables in Dynamic Panel Data Models with an Application to Firm Dividend Policy," Journal of Business and Economic Statistics 25, 462-472.

Merton, R., 1973. "Theory of Rational Option Pricing," Bell Journal of Economics and Management Science 4, 141-183.

Morellec, E., B. Nikolov, and N. Schurhoff, 2012, "Corporate Governance and Capital Structure Dynamics," Journal of Finance 67, 803-848.

Pagan, B., 1984, "Econometric Issues in the Analysis of Regressions with Generated Regressors," International Economic Review 25, 221-247.

Phan, H.V., 2014, "Inside Debt and Mergers and Acquisitions," Journal of Financial and Quantitative Analysis 49, 1365-1401. 
Roberts, M.R. and T.M. Whited, 2013, "Endogeneity in Empirical Corporate Finance," in G. Constantinides, M. Harris, and R. Stulz, Eds. Handbook of the Economics of Finance, Vol. 2, Amsterdam, The Netherlands, North Holland.

Serfling, M.A., 2014, "CEO Age and the Riskiness of Corporate Policies," Journal of Corporate Finance $25,251-273$.

Smith, C.W. and R.M. Stulz, 1985, "The Determinants of Firms' Hedging Policies," Journal of Financial and Quantitative Analysis 20, 391-405.

Sundaram, R.K. and D.L. Yermack, 2007, "Pay Me Later: Inside Debt and its Role in Managerial Compensation," Journal of Finance 62, 1551-1588.

Wang, C., F. Xie, and X. Xin, 2014, "Managerial Ownership of Debt and Corporate Financial Reporting," Chinese University of Hong Kong Working paper.

Warr, R.S., W.B. Elliot, J. Koëter-Kant, and O. Oztekin, 2012, "Equity Mispricing and Leverage Adjustment Costs," Journal of Financial and Quantitative Analysis 47, 589-616.

Wei, C. and D. Yermack, 2011, "Investor Reactions to CEOs' Inside Debt Incentives," Review of Financial Studies 24, 3813-3840. 